\title{
THE PHYSICAL AND CHEMICAL EVOLUTION OF FLUIDS IN RARE-ELEMENT GRANITIC PEGMATITES ASSOCIATED WITH THE LACORNE PLUTON, QUÉBEC, CANADA
}

\author{
Thomas MULJA ${ }^{1}$ and Anthony E. WILLIAMS-JONES \\ Department of Earth and Planetary Sciences, McGill University, \\ 3450 University St., Montréal, Québec, Canada H3A 0E8.
}

Revised version

Manuscript CHEMGE11075

Submitted to Chemical Geology

March 31, 2018

${ }^{1}$ Corresponding author. Present address: 3709 Rutherford Cres., North Vancouver, B.C., Canada V7N 2C6

email: mulja@protonmail.com 


\section{ABSTRACT}

Co-magmatic rare-element $(\mathrm{Be}, \mathrm{Li}, \mathrm{Nb}, \mathrm{Ta})$ granitic pegmatites associated with the Lacorne monzogranite pluton of the Preissac-Lacorne batholith (Québec) range from a least evolved beryl-type in the pluton through a transitional beryl + spodumene-type to a most evolved spodumene-type in mafic country rocks. They possess internal lithologic fabrics and primary fluid inclusions that provide evidence for saturation of the magma with aqueous fluids immediately after the formation of aplite in the beryl pegmatite, and pene-contemporaneously with formation of the beryl + spodumene and spodumene pegmatites. The early fluids are represented by aqueous liquid-vapor (Type 1a) and aqueous liquid-vapor-solid (Type 2) inclusions in beryl from beryl and beryl + spodumene pegmatites and are estimated to have been trapped between 500 and $550{ }^{\circ} \mathrm{C}$ and at $3.5 \mathrm{~Kb}$. On the basis of microthermometric measurements, analyses of the compositions of the precipitates from decrepitated inclusions and the nature of the solids (trapped), these fluids are interpreted to have been $\mathrm{NaCl}$-dominated ( $\leqslant 16 \mathrm{wt} . \% \mathrm{NaCl}$ eq.) and to have contained appreciable $\mathrm{Fe}$ and dissolved $\mathrm{CO}_{2}$. In spodumene pegmatite, the equivalent fluid, which was trapped at 450 to $500{ }^{\circ} \mathrm{C}$, contained significant $\mathrm{Mn}, \mathrm{Li}$ and $\mathrm{Cs}$ in place of $\mathrm{Fe}$, consistent with corresponding trends in the chemical evolution of the host rock.

Volatile-rich, mainly secondary, aqueous fluid inclusions (Type 1b) trapped in beryl are interpreted to reflect temporary sharp drops in pressure later in the crystallization history of the beryl-bearing pegmatites due to local fluid overpressures that led to brecciation and consequent pressure release. These inclusions have high salinity, are $\mathrm{CaCl}_{2}$-rich and are considered to represent magmatic hydrothermal fluids that acquired their calcium as a result of their interaction 
with the host Lacorne pluton. Incursion of $\mathrm{CaCl}_{2}$-rich fluids into the spodumene pegmatites is interpreted to have occurred earlier in their crystallization history, i.e., upon emplacement of the pegmatites, as shown by the fact that a high proportion of primary inclusions in spodumene in these pegmatites contains considerable calcium, and calcium contents are generally higher in inclusions in spodumene than in beryl. The inclusions in the spodumene pegmatites are thought to have acquired their calcium though interaction of the fluids with the amphibolites (metabasalts) that host these intrusions.

The crystallization of the pegmatites terminated with the entrapment of low-salinity aqueous-carbonic fluids (Type 3 inclusions) in quartz (6-10 wt.\% $\mathrm{NaCl}$ eq.), which most likely formed as a result of the unmixing of the magmatic fluid into separate aqueous and carbonic fluids, probably at temperatures between 250 and $350{ }^{\circ} \mathrm{C}$.

The results of this study show that aqueous fluid saturation can take place at an early stage of pegmatite emplacement, and that magma evolution is matched by changes in the solute chemistry of the exsolving aqueous fluid. They also show that evolution to a more volatile-rich composition $\left(\mathrm{H}_{2} \mathrm{O}+\mathrm{F}+\mathrm{Li}\right)$ may have contributed to the increased mobility of later magma batches, thereby helping to explain the regional zonation of the pegmatites, from beryl-type within the pluton to spodumene-type in the adjacent amphibolites.

Keywords: Rare-element granitic pegmatites, fluid inclusions, magmatic fluids, pegmatite genesis 


\section{Introduction}

Aqueous fluids are considered by some petrologists, e.g., Nabelek et al. (2010) and Thomas and Davidson (2016 and references therein), to play an important and even defining role in the genesis of granitic pegmatites, particularly Li-Cs-Ta (LCT) rare-element varieties, and by others, e.g., London (2014) to exert little or no influence in this genesis. Building on experiments by Fenn (1977) dealing with crystal nucleation and growth, Nabelek et al. (2010) showed that dissolved $\mathrm{H}_{2} \mathrm{O}$ plays a critical role in pegmatite formation by raising the free energy required for nucleation, lowering the viscosity and reducing the glass transition temperature. They argued that high $\mathrm{H}_{2} \mathrm{O}$ activity $\left(\mathrm{H}_{2} \mathrm{O}\right.$ saturation) therefore leads to delayed nucleation and rapid crystal growth, thereby promoting a pegmatitic texture in highly undercooled magmas; the corollary is that exsolution of $\mathrm{H}_{2} \mathrm{O}$ leads to a microcrystalline texture (Nabalek et al., 2010). According to Thomas and Davidson (2016), granitic pegmatites crystallize from supercritical, volatile-rich magmas that exsolve a water-poor, meta-aluminous to peraluminous melt and a water-rich peralkaline melt, which form the pegmatite core and rim, respectively, and a volatile- and alkali element-rich aqueous fluid. Like Nabelek et al. (2010), however, they argue that the required low viscosity of the magma can be achieved only with high concentrations of fluxing components, especially $\mathrm{H}_{2} \mathrm{O}$ (also see Bartels et al., 2013, 2015), and that high volatile, particularly $\mathrm{H}_{2} \mathrm{O}$, contents are needed to suppress nucleation and promote the growth of large crystals.

In contrast to Nabelek et al. (2010) and Thomas and Davidson (2016), London (2014 and references therein), on the basis of experiments in which they replicated the texture and mineralogy of pegmatites under conditions of very low $\mathrm{H}_{2} \mathrm{O}$ activity, have asserted repeatedly 
that the silicate structure modifiers B, F and $\mathrm{P}$ alone are sufficient to explain pegmatite genesis. In rejecting a role for $\mathrm{H}_{2} \mathrm{O}$, London (1992) noted that $\mathrm{H}_{2} \mathrm{O}$-saturated experiments yield products that are "distinctly unlike natural pegmatites". It is noteworthy, however, that Sirbescu et al. (2017) produced textures experimentally very similar to those of zoned pegmatites, including coarse-grained graphic, skeletal and unidirectional textures. According to London (2014), pegmatite textures are the result of "constitutional zone refining", in which crystallisation proceeds from a boundary layer liquid that is compositionally different from but continuous with the bulk liquid.

For many researchers, fluid inclusions are an essential source of information with which to constrain the physicochemical conditions of crystallization and interpret fluid evolution during pegmatite formation. For example, fluid inclusions have been used to determine the contrasting chemical compositions of fluids associated with miarolitic and non-miarolitic pegmatites (Sirbescu, 2017), P-T-X conditions during the magmatic-hydrothermal transition in gem tourmaline-bearing and barren pegmatites (Gammel and Nabelek, 2016), and the fluid evolution of beryl-bearing (Fuertes-Fuente et al., 2000; Alfonso and Melgarejo, 2008; Palinkaš et al., 2014) and lithium-bearing pegmatites (Sirbescu and Nabelek, 2003). In conjunction with melt inclusions, fluid inclusions also have been used to document silicate melt-melt-fluid immiscibility in the development of pegmatites (Thomas et al., 2009a, 2009b; Smirnov, 2015).

The present study makes use of fluid inclusion data from paragenetically early to late minerals in a suite of progressively evolved rare-element granitic pegmatites associated with the Lacorne pluton of the Preissac-Lacorne batholith in northwestern Québec, Canada. These pegmatites are regionally zoned into a least-fractionated beryl-type that intruded the pluton, a 
transitional beryl + spodumene-type around the pluton periphery, and a most-fractionated spodumene-type that was emplaced in country rocks distal to the pluton (Fig. 1). In this paper, we document the separation of an aqueous fluid from the magma, establish the timing and physicochemical conditions of this separation, and reconstruct the progressive changes in these conditions with magma evolution. We also provide an explanation for the regional zonation of the pegmatites.

\section{Geology}

The pegmatites considered in this study are part of the Lacorne pluton of the Archean Preissac-Lacorne batholith, which comprises syn-tectonic gabbro, monzonite, granodiorite and post-tectonic peraluminous monzogranite (Fig. 1), with zircon $\mathrm{U}-\mathrm{Pb}$ ages ranging from 2,619 to 2,760 Ma and from 2,611 to 2,737 Ma, respectively (Ducharme et al., 1997 and references therein). Muscovite, reportedly from the Lacorne pegmatites, yielded ${ }^{40} \mathrm{Ar} /{ }^{39} \mathrm{Ar}$ ages of 2,615 $\pm 10 \mathrm{Ma}$ to $2,594 \pm 7 \mathrm{Ma}$ (Feng et al., 1992), which were used by the authors to constrain the thermal history of the Abitibi region and not the emplacement age of the pegmatites. No information is available on the nature and type of the pegmatites that were sampled; Ducharme et al. (1997) considered them to belong to the Lamotte pluton, located west of the Lacorne pluton.

Rocks surrounding the Lacorne pluton consist mainly of basalt plus smaller volumes of basic tuffs and komatiite, which have been metamorphosed regionally to upper greenschist facies. Locally (within 7 kilometers of the batholith), they display evidence of contact metamorphism (cf. Dawson, 1966; Powell, 1994). Hornblende from metabasalt sampled along

Mulja, T. and A. E. Williams-Jones. "The Physical and Chemical Evolution of Fluids in 
a fault in the southwest of the batholith yielded $\mathrm{an}^{40} \mathrm{Ar} /{ }^{39} \mathrm{Ar}$ age of 2,633 $\pm 59 \mathrm{Ma}$ (Powell et al., 1995).

Rare-element ( $\mathrm{Li}, \mathrm{Be}, \mathrm{Nb}-\mathrm{Ta}$ ) granitic pegmatites occur in and around the Lacorne pluton, a monzogranite quasi-concentrically zoned into biotite, two-mica and muscovite variants that, according to Mulja et al. (1995b), developed as a result of sidewall crystallization. These pegmatites, which form dikes ranging from tens of centimeters to eight meters in width and lenticular bodies up to $5 \times 24 \mathrm{~m}$ in plan, are the products of fractional crystallization of the residual liquid from the Lacorne monzogranitic pluton. Within the pluton, barren quartz veins and local faults cut many pegmatites, but without substantially affecting the internal structure of these intrusive rocks, except in narrow zones along the fault planes.

On the basis of the dominant rare-element-bearing minerals, the pegmatites have been subdivided into proximal (with respect to the Lacorne pluton) beryl-, intermediate beryl + spodumene- and distal spodumene-types (Fig. 1). In the rest of this paper, they are referred to as beryl, beryl + spodumene and spodumene pegmatites. Molybdenite- and columbite-tantalite-bearing albitite dikes and molybdenite-bearing quartz veins occur beyond the spodumene pegmatite zone to the north and south of the pluton, respectively (Fig. 1).

The most important rare-element pegmatites are at the Mass Beryl Prospect (beryl-type), the Valor Prospect (beryl + spodumene-type) and the Quebec Lithium deposit (spodumene-type). Most of the samples on which this study is based were taken from these localities. The beryl pegmatites range in size from small lenses $(<1 \mathrm{~m}$ long $\times 0.1 \mathrm{~m}$ wide $)$ to $8 \mathrm{~m}$ wide dikes, and either have a sharp or gradational contact with the host pluton. This study is based on 0.5 to $1 \mathrm{~m}$ wide pegmatites. They are zoned symmetrically from a sodic aplite margin, through a medial 
assemblage of beryl, quartz, K-feldspar, muscovite, and albite, to a quartz + K-feldspar core.

Layers of fine-grained garnet and small pockets of quartz \pm muscovite are ubiquitous in the aplite (cf. Mulja et al., 1995a). The K-feldspar crystals are commonly perthitic, and some larger crystals form graphic intergrowths with quartz. Ferrocolumbite, monazite-(Ce), gahnite, molybdenite and magnetite are minor minerals.

Beryl + spodumene pegmatites are located between the beryl and spodumene pegmatites (Fig. 1). The beryl + spodumene pegmatite at Valor, which appears to be lens-shaped (it has a maximum width of $4 \mathrm{~m}$ ), is hosted in two-mica monzogranite. It has a discontinuous, corrugated and layered aplite border (Figs. 2, 3) that is locally truncated by euhedral beryl crystals up to $4 \mathrm{~cm}$ across and spodumene abutting against the monzogranite. Spessartine, garnet and tourmaline are minor phases in the aplite, though locally the latter two minerals form distinct layers. A narrow zone of muscovite books and small beryl crystals marks the transition from this marginal unit to an intermediate zone that comprises mainly 3 to $4 \mathrm{~cm}$-wide rosettes of cleavelandite (a low temperature variety of albite), quartz, K-feldspar and spodumene, and minor pollucite $\left[\left(\mathrm{Cs}, \mathrm{Na}_{2}\right)_{2} \mathrm{Al}_{2} \mathrm{Si}_{4} \mathrm{O}_{22} \cdot \mathrm{H}_{2} \mathrm{O}\right]$, manganocolumbite and pyrophanite $\left(\mathrm{MnTiO}_{3}\right)$. Spodumene in this zone ranges in size from small laths to a $20 \mathrm{~cm} \times 2$ $\mathrm{m}$ prism that extends into the pegmatite core (Fig. 2), which also contains quartz, cleavelandite and lepidolite.

The spodumene pegmatites, which were exploited by the former owner, the Québec Lithium Mine, until the middle of 1980s, currently contain 63.7 MT of combined reserve and resource at 0.94-1.19 wt $\% \mathrm{Li}_{2} \mathrm{O}$ for a cut-off grade of $0.6-0.9 \% \mathrm{Li}_{2} \mathrm{O}$ (Blanchet et al., 2012). Derry (1950) described the spodumene pegmatites as sub-parallel dikes ranging from 3- to 14-m wide, striking 
60 to $70^{\circ} \mathrm{NW}$ and dipping 40 to $60^{\circ} \mathrm{S}$. No such outcrops were encountered during the fieldwork for this study, and hence the following description is based on observations of drill core.

The spodumene pegmatite occurs as both massive and zoned varieties, ranges from small lenses to dikes, generally 1-2 m wide (a $45 \mathrm{~m}$ wide pegmatite was reported by Blanchet et al., 2012), and displays sharp or gradational contacts with the host rocks. Thin rims of holmquistite $\left[\mathrm{Li} 2\left(\mathrm{Mg}, \mathrm{Fe}^{+2}\right)_{3}\left(\mathrm{Al}_{2} \mathrm{Fe}^{+3}\right)_{2}\left(\mathrm{Si}_{8} \mathrm{O}_{22}\right)(\mathrm{OH})_{2}\right]$ replaced mafic minerals in the host rocks. The pegmatites contain $10-30 \%$ spodumene, and $30-50 \%$ each of quartz and feldspar (albite and K-feldspar). Some albite crystals have overgrowths ranging in composition from oligoclase to andesine. In the massive variety, spodumene forms $1 \mathrm{~cm} \times 3 \mathrm{~cm}$ prismatic crystals that are randomly distributed from wall to wall and oriented at 45-90 degrees to the contacts. Where present, spodumene + quartz intergrowths (squi) are considered to have replaced petalite. Occurring as subhedra to euhedra, the quartz and feldspar crystals average $5 \mathrm{~mm}$ across. The zoned spodumene pegmatites are symmetrical, consisting of a discontinuous $<5$-cm wide border aplite, an intermediate assemblage of spodumene + quartz + minor plagioclase, and a quartz-dominated core with minor spodumene + feldspar. These silicate minerals display textural relationships similar to their counterparts in the massive pegmatites. Manganocolumbite [some partially replaced by microlite $\left.(\mathrm{Na}, \mathrm{Ca})_{2} \mathrm{Ta}_{2} \mathrm{O}_{6}(\mathrm{O}, \mathrm{OH}, \mathrm{F})\right]$, pollucite, beryl and apatite are minor minerals.

Both beryl and beryl + spodumene pegmatites underwent internal brecciation. In the former pegmatite-type, the fragments are cemented by coarse-grained granite, aplite or albite, which also rims the K-feldspar (Figs 4A and 4B). This brecciation reflects excessive fluid pressure (hydraulic fracturing) prior to complete crystallization of the pegmatite, whereas the albitization 
records the transition from the magmatic to the hydrothermal stage. Brecciation of the beryl + spodumene pegmatite was accompanied by lithium metasomatism, in which clusters of subsolidus lepidolite replaced other silicate phases (Fig. 4C). In contrast to the endogenous brecciation in the aforementioned, less evolved pegmatite-types, the emplacement of spodumene pegmatites triggered the formation of fractures in the host amphibolite and biotite schist, and their filling with an albite-quartz assemblage (Fig. 4D). In addition, the fluids expelled by the pegmatite induced replacement of mafic minerals by holmquistite in the host rocks.

\section{Analytical methods}

Microthermometric measurements of phase changes in fluid inclusions were conducted on a Fluid Inc. USGS-adapted gas-flow heating and freezing stage (Werre et al., 1979). Care was taken to ensure that inclusions, which might have undergone post-entrapment modification (e.g., necking-down), were not measured. The stage was calibrated with synthetic fluid inclusions for temperatures between -56.6 and $374.1^{\circ} \mathrm{C}$, and with a quartz disk for higher temperature (the $\alpha-\beta$ transition occurs at $573^{\circ} \mathrm{C}$ ). The accuracy was \pm 0.2 and $\pm 3{ }^{\circ} \mathrm{C}$ for the low- and high-temperature measurements, respectively. A Bruker IFS-88 FT Raman spectrometer at McGill University equipped with an Olympus microscope was used to identify solids in Type 2 fluid inclusions in beryl from beryl and beryl + spodumene pegmatites. The operating conditions were a $1064 \mathrm{~nm}$ excitation frequency and a Nd-YAG laser beam power of $300 \mathrm{~mW}$. In addition, three samples of beryl and quartz were analyzed for the anion contents of the fluid inclusions using the crush-leach method (cf. Roedder, 1984, p.212-218) and a Dionex ion chromatograph at the University of Windsor in Ontario (Canada). 
The chemical compositions of precipitates or residues from decrepitated fluid inclusions and solids in opened fluid inclusions were determined with an energy-dispersive X-ray spectrometer attached to a JEOL 840 scanning electron microscope. Cleaned, doubly-polished wafers were heated in the fluid inclusion stage until the inclusions decrepitated (at temperatures less than 450 $\left.{ }^{\circ} \mathrm{C}\right)$. Because of their irregular shapes and the potential for considerable compositional heterogeneity, the precipitates on the wafer were analyzed in raster mode for 25-30 second counting times. Mineral chips opened for analyses of the included solids were frozen with liquid nitrogen, broken, and glued onto silica glass slides. The slides were coated with carbon on a rotating stage to ensure uniform coating. All analyses were carried out at McGill University.

\section{Fluid Inclusions}

Fluid inclusions were analyzed in beryl and adjacent quartz from beryl and beryl + spodumene pegmatite, and in spodumene and discrete quartz crystals from spodumene pegmatite (See Table 1 for their locations within the pegmatites); quartz intergrown with spodumene, which is interpreted to represent the replacement of petalite, lacks fluid inclusions large enough to be analyzed. Spodumene in the beryl + spodumene pegmatites is cloudy and was not suitable for fluid inclusion study. In contrast, spodumene (averaging $0.5 \times 2 \mathrm{~cm}$ in plan) from both massive and zoned spodumene pegmatites contains many large fluid inclusions.

\subsection{Petrography}

Four main types of fluid inclusion were recognized (Table 1): 1) aqueous liquid-vapor (L-V); 2) aqueous liquid-vapor-solid (L-V-S); 3) aqueous-carbonic (L-V, L-L-V and L-L-V-S); and 4) 
carbonic ( $\mathrm{L}$ and L-V). Type1 inclusions occur in all minerals examined and form the bulk of the fluid inclusion population.

\subsubsection{Type 1 inclusions}

In beryl from both beryl and beryl + spodumene pegmatites, the Type 1 inclusions are subdivided into Type 1a, which homogenize to liquid ( $70 \%$ of the Type 1 population) and Type $1 \mathrm{~b}$, which homogenize to vapor. Approximately a quarter of the Type 1a inclusions occur in three-dimensional arrays (Fig. 5A) aligned parallel to crystal boundaries, and in this environment are interpreted to be of primary origin (cf., Roedder, 1984). These Type 1a inclusions typically have ovoid or negative crystal shapes (Fig. 5B), measure 5-20 $\mu \mathrm{m}$ across and have liquid/vapor ratios between 2 and 4. Significantly, some Type 1a inclusions in beryl from beryl and beryl + spodumene pegmatites coexist with melt inclusions. The latter inclusions consist of opaque (magnetite and Fe-rich sphalerite) and translucent to transparent phases (ferroan gahnite, which has high relief, and glass, which is isotropic) (Figs. 5C, D, 6). This close spatial relationship between fluid and melt inclusions supports the interpretation that the Type 1a inclusions are primary. The remaining Type 1a inclusions are small ( $\leq 5 \mu \mathrm{m}$ in diameter), and occur along healed fractures, indicating that they are secondary, i.e., that they formed after crystallization of the host beryl. The Type $1 \mathrm{~b}$ inclusions range from 15 to $20 \mu \mathrm{m}$ in diameter and the proportion of vapor ranges from 55 to $75 \mathrm{vol} . \%$. They are generally aligned along healed fractures and are therefore mainly secondary; a small proportion occurs as isolated inclusions and might therefore be primary. However, they occur separately from the secondary Type 1a inclusions.

In contrast to Type 1 inclusions in beryl, Type 1 inclusions in quartz from the three types of

Mulja, T. and A. E. Williams-Jones. "The Physical and Chemical Evolution of Fluids in 
pegmatite and in spodumene from spodumene pegmatite all homogenize to liquid (Type 1a). The inclusions in quartz have petrographic characteristics similar to the secondary Type 1a inclusions in beryl, whereas in spodumene they occur mostly as negative prismatic crystals (up to $30 \mu \mathrm{m}$ long; most are $\pm 10 \mu \mathrm{m}$ long). The latter inclusions are typically oriented parallel to the $\mathrm{C}$-axis of the spodumene and are considered primary. Secondary Type la inclusions in spodumene are small ( $\sim 3 \mu \mathrm{m}$ in diameter) and occur along healed fractures oriented at a variety of angles to the C-axis of the crystal.

\subsubsection{Type 2 inclusions}

Type 2 (L-V-S) inclusions are hosted exclusively by beryl in beryl and beryl + spodumene pegmatites, and spodumene in spodumene pegmatite. In beryl, the Type 2 inclusions are considerably less common than Type 1 inclusions (1:10), whereas in spodumene they are only slightly less abundant than Type 1 inclusions. Type 2 inclusions in beryl and spodumene have euhedral (the norm in spodumene) to subhedral negative crystal shapes and coexist with primary Type 1a and melt inclusions (Figs. 5C, E, F). These relationships suggest that the inclusions are primary. Some Type 2 inclusions, particularly in beryl, are surrounded by halos of tiny inclusions $(\leq 1 \mu \mathrm{m}$ diameter; Fig. 5E). These inclusions are interpreted to represent implosion halos that form in response to the host to isobaric cooling, and develop due to the dissolution of silica around the inclusion and its reprecipitation within the inclusion (Bakker and Jansen, 1994; Vityk et al., 1995; Vasyukova et al., 2016).

The Type 2 inclusions in beryl typically contain one or two solids and in spodumene one solid, although up to five solids have been observed in Type 2 inclusions in both minerals. 
Inclusions having one or two solids comprise over 80 vol.\% liquid plus vapor, whereas those with more than two solids typically comprise about 70 vol.\% liquid plus vapor and in some cases as little as $40 \mathrm{vol} . \%$ of these phases. Because of an inconsistency in volumetric ratios between the solids and the fluid phases, the solids are interpreted to have been heterogeneously entrapped, i.e., they are not daughter minerals.

The most commonly occurring solid displays a prismatic shape (maximum length, $15 \mu \mathrm{m}$ ) and is milky white and anisotropic. It is present in over $80 \%$ of Type 2 inclusions in beryl, and in about $25 \%$ of these inclusions in spodumene. In opened inclusions, it has a trigonal cross-section (Figs. 7A, B) and yields energy dispersive spectra (EDS) with peaks for $\mathrm{O}, \mathrm{Al}$ and $\mathrm{Si}$ (Fig. 7C). From semi-quantitative analyses, the $\mathrm{Al} / \mathrm{Si}$ value is approximately 1.4 (Table 4), which is very different from the value for beryl $(0.33)$ and spodumene $(0.5)$ but very close to that for the tourmaline group mineral, rossmanite $\left[[]\left(\mathrm{LiAl}_{2}\right) \mathrm{Al}_{6}\left(\mathrm{Si}_{6} \mathrm{O}_{18}\right)\left(\mathrm{BO}_{3}\right)_{3}(\mathrm{OH})_{4}\right](1.33)$, which occurs most commonly as trigonal prisms (Selway et al., 1998). This mineral has been reported from other LCT pegmatites and is interpreted to represent a very late stage in the evolution of such pegmatites (Tindle et al., 2002).

The next most common mineral has a rhombic shape ( $\sim 3 \mu \mathrm{m}$ across) and is weakly to moderately birefringent. This mineral is slightly more common in spodumene than in beryl. On the basis of EDS analyses of the solids in opened inclusions, this mineral is calcite and/or magnesian calcite in beryl from beryl and beryl + spodumene pegmatites and manganoan calcite in spodumene from beryl + spodumene and spodumene pegmatite (Table 3 ). A fourth rhombic mineral, which is observed mostly in inclusions hosted by spodumene from both beryl + spodumene and spodumene pegmatites was conspicuous for the fact that it produced an EDS 
spectrum that only contained peaks for $\mathrm{C}$ and $\mathrm{O}$ in addition to those for $\mathrm{Al}$ and $\mathrm{Si}$, which are from the host (Fig. 8A). In view of this and the fact that one of the un-opened rhombic solids in beryl yielded a weak Raman peak corresponding to that of zabuyelite $\left(\mathrm{Li}_{2} \mathrm{CO}_{3}\right)$ (Fig. 8B), we conclude that this solid is zabuyelite.

Quartz and pollucite $\left[\mathrm{CsAlSi}_{2} \mathrm{O}_{6} \cdot \mathrm{H}_{2} \mathrm{O}\right.$ ], which were identified from their ED spectra, are the next most common solids; quartz occurs as subhedral prisms in inclusions in beryl and spodumene from the three types of pegmatite, whereas pollucite forms an anhedral phase in inclusions in spodumene from both beryl + spodumene and spodumene pegmatite and in quartz from spodumene pegmatite. The ED spectrum of pollucite contains a small Na peak, indicating that its composition departs slightly from that of the end-member mineral. The only other solids positively identified from their ED spectra are albite, which was found in a few inclusions, and is invariably euhedral and small ( $3 \mu \mathrm{m}$ long), $\mathrm{Nb}$-Ta oxide (a member of the columbite-tantalite family), Fe-poor sphalerite (no Fe spectral peak), barite and cassiterite, all of which are rare (Table 3).

A solid, which was found only in three Type 2 beryl-hosted inclusions, is reddish brown and roughly equidimensional. This solid, probably hematite, was invariably accompanied by one or two of the minerals described above. Finally, a Type 2 inclusion hosted by quartz from spodumene pegmatite, contained a solid that yielded an ED spectrum with peaks for $\mathrm{O}, \mathrm{Al}$ and $\mathrm{Si}$ (Fig 9B). The relative heights of these peaks are identical to those of spodumene, and we therefore conclude that the solid is spodumene. This interpretation implies that some spodumene crystallized hydrothermally. 


\subsubsection{Type 3 inclusions}

Type 3 carbonic inclusions are present mainly in quartz, rarely in beryl, and are absent from spodumene. At room temperature, these inclusions consist of two phases (liquid $\mathrm{H}_{2} \mathrm{O}$ and liquid or vapor $\mathrm{CO}_{2}$ ) or three phases (liquid $\mathrm{H}_{2} \mathrm{O}$, liquid $\mathrm{CO}_{2}$ and vapor $\mathrm{CO}_{2}$ ). The phase ratios are quite variable, even among adjacent inclusions, suggesting that $\mathrm{H}_{2} \mathrm{O}$ and $\mathrm{CO}_{2}$ were immiscible and heterogeneously entrapped. Rare Type 3 inclusions in quartz from the beryl + spodumene pegmatite contain rossmanite. Most Type 3 inclusions have negative to subhedral crystal shapes and are commonly isolated. Locally, Type 3 inclusions coexist with primary Type 1a inclusions in three dimensional arrays indicating that they are primary. Both types of inclusion are present in similar proportions in quartz from beryl and beryl + spodumene pegmatites, but Type 3 inclusions are less common than Type 1 inclusions in quartz from spodumene pegmatite. A small proportion of Type 3 inclusions occurs along healed fractures, indicating that these inclusions are of secondary origin.

\subsubsection{Type 4 inclusions}

Type 4 inclusions are present only in quartz from beryl and beryl + spodumene pegmatites. The majority of these inclusions are irregularly-shaped and occur along healed fractures, indicating their secondary origin. At room temperature $\left(23^{\circ} \mathrm{C}\right)$, the inclusions consist of liquid or liquid and vapor. The liquid inclusions nucleate a vapor bubble upon cooling.

\subsection{Microthermometry}


The results of the microthermometric analyses of the fluid inclusions are summarized in Table 1. Initial, or quasi-eutectic, ice-melting temperatures (Te) were difficult to observe in many inclusions, and consequently, only a small number of measurements was made. Fluid salinity (in weight percent $\mathrm{NaCl}$ equivalent) was calculated from the final ice melting temperature ( $\mathrm{T}_{\mathrm{m}}$ ice) using the equation of Bodnar (1993) for Type 1 and 2 inclusions, and from the final melting temperature of clathrate ( $T_{\mathrm{mclath}}$ ) using the equation of Darling (1991) for Type 3 inclusions.

\subsubsection{Type 1 inclusions $(L-V)$}

The ice in the majority of primary and secondary Type $1 \mathrm{a}$ and $1 \mathrm{~b}$ fluid inclusions in the different minerals from the three pegmatite types started to melt at a temperature lower than the eutectic temperature of the $\mathrm{H}_{2} \mathrm{O}-\mathrm{NaCl}$ system of $-21.2{ }^{\circ} \mathrm{C}$ (Davis et al., 1990), or its metastable eutectic of $-27.1{ }^{\circ} \mathrm{C}$ (Drebushchak et al., 2016), and the eutectic temperature of the $\mathrm{H}_{2} \mathrm{O}-\mathrm{NaCl}-\mathrm{KCl}$ system of $-22{ }^{\circ} \mathrm{C}$ (Sterner et al., 1988) (Fig. 10). This indicates that, in addition to $\mathrm{NaCl} \pm \mathrm{KCl}$, salts such as $\mathrm{FeCl}_{2}, \mathrm{CaCl}_{2}$ and perhaps $\mathrm{LiCl}$, were also present in the fluids.

On the basis of their initial temperature of ice melting, Type 1a fluid inclusions in beryl and spodumene from the three pegmatite types appear to be enriched in $\mathrm{FeCl}_{2}$ and depleted in $\mathrm{CaCl}_{2}$ relative to Type $1 \mathrm{~b}$ fluid inclusions in the same minerals, and in quartz from all pegmatite types (Fig. 9). Support for this interpretation is provided by the compositions of precipitates from decrepitated fluid inclusions (reported below). Evidence for populations of low and high Ca-bearing fluid inclusions is also provided by Figure 9 and Table 1, in which it can be seen that fluid inclusions with an initial ice-melting temperature above $-20.8{ }^{\circ} \mathrm{C}$ have low salinity and

Mulja, T. and A. E. Williams-Jones. "The Physical and Chemical Evolution of Fluids in Rare-Element Granitic Pegmatites Associated with the Lacorne Pluton, Quebec, Canada." Chemical Geology 493 (Aug 20 2018): 281-97. http://dx.doi.org/10.1016/j.chemgeo.2018.06.004. 
those with a lower initial ice-melting temperature have higher salinity. Most of the primary Type 1a inclusions in the three pegmatite types underwent final ice-melting at a temperature between -10 and $-0.3{ }^{\circ} \mathrm{C}$, which corresponds to a salinity between 14 and $0.5 \mathrm{wt} . \% \mathrm{NaCl}$ eq. (Fig. 10). The few primary Type 1a inclusions in spodumene and quartz from spodumene pegmatite with a low temperature of initial ice-melting underwent final melting of ice at temperatures from -35 to -40 ${ }^{\circ} \mathrm{C}$. This supports the conclusion that they probably contain significant concentrations of $\mathrm{CaCl}_{2}$. If the compositions of these fluid inclusions are modeled in the system $\mathrm{NaCl}-\mathrm{CaCl}_{2}-\mathrm{H}_{2} \mathrm{O}(\mathrm{O}$ akes et al., 1990), the minimum weight fractions, $\mathrm{CaCl}_{2} /\left(\mathrm{CaCl}_{2}+\mathrm{NaCl}\right)$, are 0.8 and 0.9 , respectively. The final melting temperature of ice in Type $1 \mathrm{~b}$ inclusions in beryl from beryl pegmatite is mainly between -25 and $-15{ }^{\circ} \mathrm{C}$, which corresponds to a salinity of between 25.6 and 19 wt. $\% \mathrm{NaCl}$ eq.

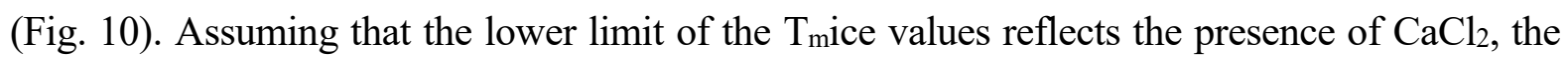
corresponding minimum weight fraction of $\mathrm{CaCl}_{2} /\left(\mathrm{CaCl}_{2}+\mathrm{NaCl}\right)$ is 0.7 . The same inclusion-type in beryl from beryl + spodumene pegmatite has a range of $\mathrm{T}_{\mathrm{m}}$ ice values from -20.2 to $-6.2{ }^{\circ} \mathrm{C}$, which corresponds to a salinity range of 22.5 to $9.5 \mathrm{wt} . \% \mathrm{NaCl}$ eq. Secondary Type 1 inclusions in beryl and quartz from both beryl and beryl + spodumene pegmatites have $\mathrm{T}_{\mathrm{m}}$ ice values between -25 and $-10^{\circ} \mathrm{C}$, which correspond to a salinity of 25.6 to 14 wt.\% $\mathrm{NaCl}$ eq. (Fig. 10).

Although Type 1a inclusions homogenized at temperatures from 150 to at least $550{ }^{\circ} \mathrm{C}$ (upper limit of the stage) in beryl, from 150 to $350{ }^{\circ} \mathrm{C}$ in spodumene, and from 150 to $400{ }^{\circ} \mathrm{C}$ in quartz, the majority of Type 1a inclusions in the three types of pegmatite have modes of homogenization temperature (Th) between 200 and $350{ }^{\circ} \mathrm{C}$ (Fig. 10). In contrast, Type $1 \mathrm{~b}$ inclusions in beryl from both beryl and beryl + spodumene pegmatites homogenized at 300 to 550 
${ }^{\circ} \mathrm{C}$. Secondary inclusions in beryl and quartz from the two pegmatite types homogenized between 150 and $550{ }^{\circ} \mathrm{C}$ with no apparent mode, but those in quartz from beryl pegmatite have a lower average Th than their equivalents in beryl + spodumene pegmatite. These low and high Th values correspond to the low and high salinity values of the fluids.

\subsubsection{Type 2 inclusions (L-V-S)}

The initial temperature of ice-melting of Type 2 inclusions ranged from -25 to $-10{ }^{\circ} \mathrm{C}$ in beryl from beryl pegmatite (Fig. 9), indicating that the fluid was dominated by $\mathrm{NaCl} \pm \mathrm{KCl}$. By contrast, this temperature for Type 2 inclusions in spodumene from spodumene pegmatite varied from -45 to $-10{ }^{\circ} \mathrm{C}$, suggesting, as in the case of Type 1 inclusions, that the fluid contains appreciable concentrations of $\mathrm{CaCl}_{2}$ and/or $\mathrm{FeCl}_{2}$. The final temperature of ice-melting of Type 2 inclusions in the three types of pegmatite ranged from -10 to $-3{ }^{\circ} \mathrm{C}$, corresponding to a salinity between 5 and 14 wt.\% $\mathrm{NaCl}$ eq., which is similar to that of the Type 1a inclusions (Fig. 10).

The liquid and vapor in Type 2 inclusions generally homogenized to liquid between 200 and $300^{\circ} \mathrm{C}$ in the three pegmatite types, and in many inclusions hosted by spodumene, a rhombic solid dissolved at a temperature between 382 and $530{ }^{\circ} \mathrm{C}$ (Fig. 10). This rhombic mineral is thus probably zabuyelite, as calcite displays retrograde solubility over a wide range of pressure-temperature conditions and fluid composition (Fein and Walther, 1987, 1989). Significantly, zabuyelite in spodumene-hosted fluid inclusions from the Jiajika pegmatite, China (Li and Chou,2017) dissolved over a similar temperature range. Consistent with the above interpretation, the rhombic solid in Type 2 inclusions hosted by beryl (calcite and magnesian 
calcite) and, in some cases, spodumene (manganoan calcite) did not dissolve even at the maximum temperature for the stage of $550^{\circ} \mathrm{C}$, indicating that it is calcite.

\subsubsection{Type 3 inclusions (aqueous carbonic)}

As noted earlier, the proportions of the carbonic and aqueous phases of Type 3 inclusions vary significantly. This was quantified by calculating $\mathrm{XCO}_{2}$ values $\left(\mathrm{CO}_{2}\right.$ is the dominant carbonic component, see below) using the method of Bodnar (1983); the values of this parameter range from 0.02 to 0.3 (most of the inclusions have $\mathrm{XCO}_{2}$ values between 0.06 and 0.1 ; Table 1 ). The initial temperature of melting of the aqueous phase varied from -40 to $-15^{\circ} \mathrm{C}$, but was mainly

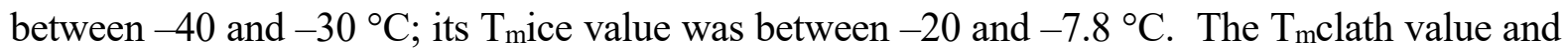
the corresponding salinity were between 5 and $7^{\circ} \mathrm{C}$, and 12.5 and $5 \mathrm{wt} . \% \mathrm{NaCl}$ eq., respectively.

The final melting temperature of the carbonic solid $\left(\mathrm{T}_{\mathrm{mCO}}\right)$ was mostly between -58.1 and $-56.6^{\circ} \mathrm{C}$, which indicates that the carbonic fluid is dominated by $\mathrm{CO}_{2}\left(\mathrm{CO}_{2}\right.$ has a melting point of $-56.6^{\circ} \mathrm{C}$; Angus et al., 1976). However, the low $\mathrm{T}_{\mathrm{m}} \mathrm{CO}_{2}$ values of some inclusions in spodumene pegmatite indicate that they contain appreciable $\mathrm{CH}_{4} \pm \mathrm{N}_{2}$. The maximum estimated value of $\mathrm{XCH}_{4}$ eq. (this refers to the proportion of $\mathrm{CH}_{4}$ in the carbonic phase), calculated using the method of Heyen et al. (1982), is 0.24 .

The $\mathrm{CO}_{2}$ liquid and vapor homogenized to either liquid, vapor, or rarely, a critical fluid. This phase transformation occurred at a temperature from -1 to $31^{\circ} \mathrm{C}$, but mostly between 11 and 31 ${ }^{\circ} \mathrm{C}$. Complete homogenization of these inclusions was either to the $\mathrm{CO}_{2}$ phase or the $\mathrm{H}_{2} \mathrm{O}$ phase and occurred at a temperature from 150 to $400{ }^{\circ} \mathrm{C}$ (Table 1); the mean temperature was $260{ }^{\circ} \mathrm{C}$ for

Mulja, T. and A. E. Williams-Jones. "The Physical and Chemical Evolution of Fluids in 
inclusions in quartz from beryl and beryl + spodumene pegmatites.

\subsubsection{Type 4 inclusions (carbonic $L-V$ )}

In most cases, the final melting temperature of the carbonic solid was between -57.6 and $-56.6{ }^{\circ} \mathrm{C}$, and there was a well-defined peak between -57.1 and $-56.6^{\circ} \mathrm{C}$, indicating that the carbonic phase consists almost entirely of $\mathrm{CO}_{2}$. The homogenization temperature of Type 4 inclusions varied mainly from 11 to $31.1{ }^{\circ} \mathrm{C}$ in beryl pegmatite and from 15 to $27{ }^{\circ} \mathrm{C}$ in beryl + spodumene pegmatite.

\subsection{Decrepitate compositions}

A total of 127 analyses were made of the compositions of the residues of decrepitated fluid inclusions in beryl from beryl and beryl + spodumene pegmatite, and in spodumene from spodumene pegmatite, and in quartz from each of the pegmatite types. Because of the irregular shapes of the residues and the potential for considerable compositional heterogeneity, they were analyzed in raster mode. The results of these analyses are summarized in Table 4.

Cation contents: The data indicate that $\mathrm{Na}^{+}$is the dominant cation in all inclusions, that $\mathrm{Ca}^{2+}$ and $\mathrm{Fe}^{2+}$ are relatively abundant in some inclusions, that $\mathrm{K}^{+}$is generally a minor constituent and that measurable proportions of $\mathrm{Mn}^{2+}$ are present only in precipitates from spodumene pegmatite. In the case of beryl and beryl + spodumene pegmatites, beryl-hosted precipitates form two populations characterized by low and moderately high Ca contents (up to $10 \mathrm{wt} \%$ ), respectively. In contrast, most spodumene-hosted decrepitates from spodumene pegmatite have moderately high $\mathrm{Ca}$ contents (averaging 10 wt.\%). Although we could not relate the low and high $\mathrm{Ca}$ 
decrepitates directly to fluid inclusion types, it is probable that the low Ca decrepitates represent former primary fluid inclusions. This is because primary Type 1a inclusions have low salinity (Fig. 10). If this were the case, it follows that Fe in the primary fluids decreased from beryl to spodumene pegmatite, whereas $\mathrm{K}$ and $\mathrm{Mn}$ increased; the Ca content increased abruptly from beryl + spodumene to spodumene pegmatite (Fig. 11). Precipitates from inclusions hosted by quartz in the three pegmatite types all only contained $\mathrm{Na} \pm \mathrm{Ca}$.

Anion contents: Chlorine was present in appreciable proportions in all precipitates, whereas sulfur, where detected, was generally in concentrations $\leq 1 \mathrm{wt} . \%$ (Table 4). Although, $\mathrm{Cl}$ and S were the only anionic elements detected and sulfate was identified in ion chromatographic analyses of reconnaissance crush-leach solutions, the precipitate compositions reflect a consistent excess positive charge, indicating that an important anionic component was not analyzed. The most likely candidate for this anion is $\mathrm{HCO}_{3}{ }^{-}$as other potential candidates, e.g., $\mathrm{Br}^{-}, \mathrm{PO}_{4}{ }^{3-}$, or organic anions would have been detected with the ion chromatograph. Anions such as $\mathrm{HCO}_{3}{ }^{-}$and $\mathrm{SO}_{4}{ }^{2-}$ are common in melt and fluid inclusions in beryl and quartz from other rare-element pegmatites (Thomas et al., 2012).

\section{Oxygen Isotope Analyses}

Oxygen isotope compositions of quartz and garnet in beryl and beryl + spodumene pegmatites were determined at the University of Saskatchewan in order to provide estimates of the temperature of equilibration of these minerals in their respective pegmatites. The $\delta^{18} \mathrm{O}$ values (referenced to SMOW) of quartz and garnet from the beryl and beryl + spodumene pegmatites are 9.3 and $5.1 \%$, and 9.6 and $5.9 \%$, respectively, corresponding to equilibrium fractionation 
temperatures of $470 \pm 50^{\circ} \mathrm{C}$ and $540 \pm 50^{\circ} \mathrm{C}$ using the equations of Clayton et al. (1972) and Bottinga and Javoy (1975). These isotopic data were also used to estimate the $\delta^{18} \mathrm{O}$ values of the coexisting water, which, based on the equation of Clayton et al. (1972), is calculated to have been 6.6 and $7.8 \%$, respectively. These values are within the range of $\delta^{18} \mathrm{O}$ values for magmatic water (Taylor and Sheppard, 1986).

\section{Discussion}

\subsection{Crystallization conditions and timing of fluid exsolution}

As mentioned previously, the first zone to crystallize in the Lacorne beryl and beryl + spodumene pegmatites, and in some spodumene pegmatites, was aplite. This aphanitic rock-type has been interpreted by many igneous petrologists to be the product of rapid crystallization or quenching of silicate melts (Jahns and Tuttle, 1963; Lowenstern, 1995; Webber et al., 1999; London, 2009), and the latter is thought by some to be induced by exsolution of an aqueous phase (Jahns and Tuttle, 1963; Lowenstern, 1995). In the case of the Lacorne pegmatite-forming magma, which remained water-undersaturated during its ascent, the presence of primary fluid inclusions in beryl from beryl and beryl+ spodumene pegmatites and in spodumene from spodumene pegmatite indicates that the exsolution of aqueous fluid occurred immediately after

the solidification of aplite for the beryl pegmatite, but pene-contemporaneously with or soon after the emplacement of beryl + spodumene and spodumene pegmatites because the host minerals were among the earliest liquidus phases to crystallize along the pegmatite border zone. 
Considering that the solubility of water in silicate melts is mainly pressure-dependent (Tuttle and Bowen, 1958; Behrens and Gaillard, 2006), we propose that decompression of the magma early in the emplacement history of the Lacorne pegmatites induced saturation of an aqueous fluid. We further propose that the exsolved fluid quenched the magma to aplite and escaped into the residual pegmatitic melt (the bulk of the fluid), an interpretation that is supported by the presence of primary Type 1a and Type 2 fluid inclusions in beryl crystals of the intermediate zone. In principle, some of this fluid should also have infiltrated the wall-rocks. Although we have no evidence of this for the beryl and beryl + spodumene pegmatites, some spodumene pegmatites are surrounded by amphibolite (metabasalt) in which mafic minerals were replaced by holmquistite (see Section 2). This also indicates that fluid exsolution endured until the terminal stages of pegmatite petrogenesis. Finally, as discussed below, we propose that the decompression was facilitated by the emplacement of the Lacorne pegmatites as dikes.

According to Brisbin (1986), dike emplacement begins when the host rock undergoes elastic deformation and brittle fracture at the crack tip as a result of hydraulic overpressures in the intruding magma that overcome the combined effects of the normal and tensile strength of the host rock. The dike thus grows by dilation perpendicular to the fractures (Brisbin, 1986) and by self-propagation (Baker, 1998). This melt-driven expansion causes decompression, particularly in the fracture tip, where the pressure is sufficiently low to cause local exsolution of an aqueous phase from the melt (Clemens and Mawer, 1992; Engvik et al., 2005).

Finally, we note that the early coexistence of aqueous fluid with pegmatite-forming melts also has been reported for rare-element pegmatites elsewhere, notably for the Olary Block $\mathrm{Be}+$ $\mathrm{Nb}$ pegmatites, South Australia (Lu and Lottermoser, 1997), ), the Borborema Be $+\mathrm{Ta}+(\mathrm{Li}-\mathrm{Sn})$ 
pegmatites (Beurlen et al., 2001) and the Harney Peak Li + Cs pegmatites (Sirbescu and Nabelek, 2003.

\subsection{Pressure-temperature conditions}

Estimates of the pressure of emplacement of the Preissac-Lacorne batholith range from 3.6 $\mathrm{Kb}$ for the pegmatites to $4.9 \mathrm{~Kb}$ for the monzogranites, based on applications of the plagioclase-garnet-muscovite-biotite geothermobarometer (Feng and Kerrich, 1990), from 2.5 to $4 \mathrm{~Kb}$, based on multi-equilibrium modeling (most equilibria intersect at $3.5 \mathrm{~Kb}$ ) of contact metamorphic assemblages (Powell, 1994) and from 1.1 to $4.9 \mathrm{~Kb}$ (averaging 1.9 Kb, $\mathrm{n}=14$ ), based on application of the normative Qtz-Ab-Or crystallization geobarometer of Yang (2017) to the monzogranites. The reason for the large gap between the maximum and minimum pressure predicted by the last method is unknown but may reflect a high sensitivity to the Qtz normative value. Thus, we believe, as proposed by Powell (1994), that the most reasonable explanation for the discrepancy between his estimates and those of Feng and Kerrich (1990) is that the emplacement pressure was approximately $3.5 \mathrm{~Kb}$, and that the higher pressure obtained by Feng and Kerrich (1990) for the monzogranites reflects a deeper-seated pre-emplacement condition. This interpretation is consistent with conclusions of both studies that regional metamorphic pressures in this part of the Abitibi greenstone belt did not exceed $4 \mathrm{~Kb}$.

Minimum estimates of the temperature of crystallization of the pegmatites are provided by the oxygen isotopic compositions of quartz and garnet, which yielded fractionation temperatures of 470 and $540{ }^{\circ} \mathrm{C}$. We have made other estimates of temperature by projecting isochores from the homogenization temperatures of Type $1 \mathrm{a}$ and $\mathrm{b}$ inclusions using the program FLINCOR in 
conjunction with the equation of state of Brown and Lamb (1989). Limiting isochores, representing the mean isochore plus or minus one standard deviation, are shown in Figure 12 for primary Type 1a and $1 \mathrm{~b}$ inclusions (mainly secondary) in beryl from beryl pegmatite, in primary Type 1a inclusions in beryl from beryl + spodumene pegmatite and in spodumene from spodumene pegmatite. The standard deviation for isochores of Type 1a inclusions hosted by quartz is much larger, due probably to the higher frequency of secondary inclusions in quartz and the difficulty of distinguishing them from primary inclusions. For this reason and for purposes of clarity, only mean isochores are plotted for inclusions hosted by this mineral. Also shown are the temperatures estimated from oxygen isotopic fractionation between quartz and garnet from beryl and beryl + spodumene pegmatites, the phase boundary for the reaction petalite $\leftrightarrows$ spodumene + quartz (London, 1984), the beryl saturation temperature range from Eversen et al. (1999) and the $3.5 \mathrm{~Kb}$ isobar estimated by Powell (1994) for the emplacement of the Preissac-Lacorne batholith. With the exception of local decompression in beryl and beryl + spodumene pegmatites, the pressure remained relatively constant throughout the cooling history of the Lacorne pegmatites, as indicated by the implosion halos around primary Type 2 fluid inclusions in beryl (Fig. 5E).

Based on a $3.5 \mathrm{~Kb}$ emplacement pressure, the trapping temperature of primary Type 1a inclusions in beryl from beryl and beryl + spodumene pegmatites is estimated to have been between 500 and $560{ }^{\circ} \mathrm{C}$. The corresponding temperature estimates for the Type $1 \mathrm{~b}$ (secondary) inclusions ( 790 to $860{ }^{\circ} \mathrm{C}$; not shown) exceed the solidus temperature $\left(650^{\circ} \mathrm{C}\right)$ estimated for the co-magmatic muscovite monzogranite (Mulja et al., 1995b) and are clearly incorrect. The most plausible explanation for this is that pressure decreased sharply between the entrapment of Type 
$1 \mathrm{a}$ and $1 \mathrm{~b}$ fluid inclusions because of a change from lithostatic to near hydrostatic conditions. Field evidence for this is the strong local brecciation (Figs. 4A-D), which reflects hydrofracturing prior to complete crystallization of the pegmatite-forming melt. The hydrostatic pressure, corresponding to a lithostatic pressure of $3.5 \mathrm{~Kb}$, is approximately $1.7 \mathrm{~Kb}$ and, based on this pressure, the trapping temperature of Type $1 \mathrm{~b}$ inclusions in beryl from beryl pegmatite was between 460 and $520{ }^{\circ} \mathrm{C}$ (Fig. 12). This temperature range overlaps that of primary Type 1a inclusions. A similar reduction in pressure elsewhere in the Preissac-Lacorne batholith was interpreted by Taner et al. (1988), who related the formation of molybdenite ore veins in the Preissac pluton to a change from lithostatic to hydrostatic conditions.

The limiting isochores for primary Type 1a inclusions in spodumene from spodumene pegmatite predict much lower trapping temperatures than those for beryl in the other two pegmatite types, i.e., they intersect the $3.5 \mathrm{~Kb}$ isobar between 450 and $480{ }^{\circ} \mathrm{C}$. The high standard deviation for isochores defined by Type 1a inclusions in quartz renders these inclusions less useful in estimating trapping temperatures. Indeed, for all three pegmatite types, they predict trapping temperatures greater than one standard deviation below the mean temperature predicted by isochores for Type 1a inclusions in beryl and spodumene. These temperatures for quartz in beryl pegmatite, beryl + spodumene pegmatite and spodumene pegmatite are, 480,450 , and $430{ }^{\circ} \mathrm{C}$, respectively.

In summary, various lines of evidence suggest that the Lacorne rare element pegmatites were emplaced at approximately $3.5 \mathrm{~Kb}$, that beryl crystallized between 500 and $560{ }^{\circ} \mathrm{C}$, that spodumene crystallization continued to temperatures as low as $450{ }^{\circ} \mathrm{C}$ and that quartz continued to crystallize at even lower temperature. 


\subsection{Composition of the fluids}

From the data already presented, it is evident that the fluids which circulated in the pegmatites were dominantly aqueous, that they varied considerably in composition, and that during later stages in the emplacement history, they coexisted with an immiscible $\mathrm{CO}_{2}$-rich carbonic fluid. On the basis of the microthermometric data for Type 1 inclusions $(\mathrm{L}-\mathrm{V})$, the aqueous fluids were subdivided into a low-salinity fluid (10 $\pm 6 \mathrm{wt} \% \mathrm{NaCl}$ eq.) represented by all primary Type 1a inclusions and some secondary Type 1a inclusions, and a high- salinity fluid (19 $\pm 5 \mathrm{wt} \% \mathrm{NaCl}$ eq.) represented by Type $1 \mathrm{~b}$ (largely secondary) and secondary Type 1a inclusions. The Type 2 inclusions (LVS) display the same microthermometric behavior as the primary Type 1a inclusions, except in spodumene pegmatite, where some display a low initial temperature of ice melting and low Tmice values. With the exception of the zabuyelite in some spodumene-hosted inclusions in spodumene pegmatite, the solids do not dissolve on heating. This and the inconsistency in the volumetric ratios of the solids to the fluid phases, indicate, as noted earlier, that the solids are trapped phases. We therefore interpret the Type 2 inclusions to also represent samples of the low salinity fluid, except locally in spodumene pegmatite.

Further insight into the chemistry of the aqueous fluids is provided by the compositions of the precipitates of decrepitated fluid inclusions. Unfortunately, we cannot relate these data unequivocally to the different types of aqueous inclusions described above. The compositions of the decrepitates show that $\mathrm{Na}^{+}$and $\mathrm{Cl}^{-}$are the principal ions in the aqueous inclusions irrespective of the nature of the host mineral or the pegmatite type (Table 4). They also show that the aqueous fluids can be further subdivided into Ca-poor and Ca-rich varieties. As all Type 1b fluid 
inclusions (restricted to beryl from beryl and beryl + spodumene pegmatites) and some Type 1a inclusions, have a relatively low temperature of initial ice melting $\left(-30\right.$ to $\left.-70{ }^{\circ} \mathrm{C}\right)$, and most Type $1 \mathrm{~b}$ and some Type 1a inclusions have high salinity, we consider that these inclusions (mainly secondary) trapped the Ca-rich fluid. A Ca-rich fluid also is interpreted to have been trapped by some high salinity Type 2 inclusions and low salinity Type 1a inclusions in spodumene pegmatite, as most fluid inclusion decrepitates from samples of this pegmatite type contain significant calcium (Table 4). The Ca-poor fluid is probably represented largely by the low salinity Type 1a and Type 2 inclusions in beryl and beryl + spodumene pegmatite, as these inclusions display a relatively high temperature of initial ice melting. Next to $\mathrm{Na}$ and $\mathrm{Ca}, \mathrm{Fe}$ was the most important cationic component of the aqueous fluids, but was only present in significant quantities in fluids trapped by beryl (both Ca-rich and -poor types) in beryl and beryl + spodumene pegmatites. Potassium was present in Ca-poor and -rich fluids trapped by beryl in beryl + spodumene pegmatite, and $\mathrm{Mn}$ in Ca-rich fluids trapped by spodumene in spodumene pegmatite. Bicarbonate was probably an important anionic component in all the aqueous fluids, judging by the large excess positive charge calculated from the decrepitate compositions, the importance of carbonate minerals as trapped solids and the absence of evidence for another significant anionic component, apart from sulfate, which is inferred to have been present in small quantities in fluids (both Ca-rich and -poor) trapped by beryl + spodumene and spodumene pegmatites.

The occurrence of pollucite and zabuyelite in the Type 2 inclusions in one or more of the three pegmatite types provides evidence that one of the fluids, probably the low salinity, Ca-poor fluid, was also enriched in $\mathrm{Cs}$ and $\mathrm{Li}$. Additional evidence of the enrichment in $\mathrm{Li}$ is provided by the formation of holmquistite $\left[\mathrm{Li} 2\left(\mathrm{Mg}, \mathrm{Fe}^{+2}\right)\left(\mathrm{Al}, \mathrm{Fe}^{+3}\right)_{2}\left(\mathrm{Si}_{8} \mathrm{O}_{22}\right)(\mathrm{OH})_{2}\right]$ in amphibolite 
(metamorphosed basalt) adjacent to the pegmatites. Moreover, high Li contents in the fluid are also predicted by the calculations of Wood and Williams-Jones (1993) for fluid-mineral equilibria involving spodumene and feldspars.

\subsection{Fluid Evolution}

From the occurrence of primary aqueous fluid inclusions in beryl and spodumene crystals located at the walls of pegmatite dikes, it is evident that aqueous fluids were present at an early stage of pegmatite crystallization (see section 6.1), and that these fluids are represented by primary Type 1a and/or Type 2 inclusions in beryl and spodumene. It is also reasonable to conclude, as we did earlier, that the early fluid was dominantly magmatic. As discussed in section 6.3, this fluid was Ca-poor, had low salinity and contained significant concentrations of $\mathrm{Na}, \mathrm{Fe}, \mathrm{Li}$ and probably $\mathrm{K}$ and $\mathrm{S}$.

The chemistry of the fluid changed gradually from Fe-rich to Li-,Mn- and K-rich until late in the crystallization history of the beryl and beryl + spodumene pegmatite types, when there was a sharp drop in pressure, recorded by the brecciation of the incompletely crystallized pegmatite. This event marked the incursion of high-salinity, Ca-bearing fluids, and occurred early in the crystallization history of the spodumene pegmatites, as indicated by the fact that, unlike primary fluid inclusions in beryl and beryl-spodumene pegmatites, some primary fluid inclusions in spodumene pegmatite are relatively rich in calcium. These latter inclusions likely represent magmatic fluids that were expelled from the crystallizing pegmatite into the amphibolite host which they brecciated. They also produced an albite-quartz assemblage that cemented the breccia fragments, and induced holmquistite replacement of mafic minerals in the

Mulja, T. and A. E. Williams-Jones. "The Physical and Chemical Evolution of Fluids in 
host rock. During their evolution, the fluids became enriched in Ca through their interaction with the amphibolite and, as a result, replaced the rims of albite crystals with oligoclase-andesine, precipitated apatite and partially replaced manganocolumbite with microlite. Such features are absent in the beryl and beryl + spodumene pegmatites.

The next and final event in the crystallization history of the pegmatites was the appearance of an immiscible $\mathrm{CO}_{2}$-dominated fluid (Type 3 inclusions) coincident with the crystallization of late quartz $\left(\mathrm{CO}_{2}\right.$-bearing fluid inclusions are restricted to quartz, i.e., they are not observed in beryl or spodumene). Possible explanations for the origin of the carbonic phase are: 1) that it was introduced from the country rocks; and 2) that the magmatic fluid contained small amounts of $\mathrm{CO}_{2}$, which started to exsolve when the pegmatite cooled to a temperature low enough for the fluid to enter the two-phase field of the system $\mathrm{H}_{2} \mathrm{O}-\mathrm{CO}_{2}$. We favor the second explanation mainly because, if the $\mathrm{CO}_{2}$ came from the country rocks, it is reasonable to expect that it would have accompanied introduction of the Ca-brine and therefore have been trapped not only in quartz but also in beryl and particularly spodumene. The presence of calcite and zabuyelite $\left(\mathrm{Li}_{2} \mathrm{CO}_{3}\right)$ in the Type 2 fluid inclusions, and the low $\mathrm{Ca}$ content of the magmatic fluid implies that, although in absolute terms, the proportion of $\mathrm{CO}_{2}$ was probably low, its content may still have been high relative to that of other components of the magmatic fluid. The $\mathrm{CO}_{2}$ would have remained in solution until the fluid cooled to temperatures well below the consolute point for the system 6 wt. $\%$ NaCl- $\mathrm{H}_{2} \mathrm{O}-\mathrm{CO}_{2}\left(400{ }^{\circ} \mathrm{C}\right.$; Bowers and Helgeson, 1983). Based on the homogenization temperatures of Type 3 fluid inclusions (Table 1), this may have been around $260 \pm 40^{\circ} \mathrm{C}$. We therefore propose that the magmatic fluid exsolved small proportions of $\mathrm{CO}_{2}$, which were preferentially trapped with variable amounts of water as Type 3 inclusions, and that 
restriction of these inclusions to late quartz reflects the low temperature required for fluid unmixing. The absence of evidence for post-entrapment unmixing of the magmatic fluids trapped at higher temperature is consistent with the lack of evidence of $\mathrm{CO}_{2}$ in Type 1a or 2 fluid inclusions. The above interpretation notwithstanding, we cannot exclude the possibility, particularly for the spodumene pegmatites, which contain a small proportion of inclusions with significant $\mathrm{CH}_{4} \pm \mathrm{N}_{2}$, that there might have been some contribution of carbonic fluid from the country rocks. After crystallization, aqueous and carbonic fluids continued to circulate in the pegmatites until relatively low temperature and are now represented by secondary Type 1 , Type 3 and Type 4 ( $\mathrm{CO}_{2}$-only) inclusions.

\subsection{Regional zonation of the pegmatite types}

Although the regional zoning of rare-element granitic pegmatite types like that documented for the Lacorne pluton (Fig. 1) has been known for over a century (see Heinrich, 1953), the origin of this zonation remains an enigma in the petrology of granitic pegmatites, especially for the LCT type. Two main petrogenetic models have been proposed to explain this distribution of pegmatite types, namely magmatic differentiation and a hybrid model involving partial melting and fractional crystallization.

Černý $(1991,1992)$, in advocating the magmatic differentiation model, proposed that the least evolved, relatively high viscosity (thus low mobility) beryl pegmatite magmas are emplaced within or close to the parental pluton, whereas the evolved, volatile-rich, low viscosity and thermally stable $\mathrm{Li}+\mathrm{Cs} \pm$ Ta magmas move considerable distances into the country rocks before they reach their liquidus temperature. This model has been embraced recently by Hulsbosch et al.

Mulja, T. and A. E. Williams-Jones. "The Physical and Chemical Evolution of Fluids in 
(2014). In contrast, London (2005), although also advocating magmatic differentiation, proposed that each of the pegmatite subtypes originates from a different part of a zoned magma chamber, with the more evolved pegmatites originating near the top. Magma withdrawal from such a magma chamber, however, is unlikely to be systematic (e.g., Blake, 1981; Matthews et al., 1999). Moreover, the sequence of withdrawal is likely to commence with the more evolved and lower temperature magma, such as is the case for the Fuji (Watanabe et al., 2006) and Bishop Tuff (Hildreth and Wilson, 2007) magma chambers. This emplacement order is opposite to that observed at Lacorne and for most other zonally distributed LCT pegmatites.

The hybrid model involves multiple batches of magma derived by varying degrees of partial melting of a geochemically homogeneous or heterogeneous protolith, each of which follows its own fractionation path. According to this model, the beryl pegmatites would reflect higher degrees of partial melting in a high temperature core zone and therefore be concentrated in the central part of the pegmatite field, whereas the lithium and more evolved tin pegmatites reflect lower degrees of partial melting at the lower temperature edge of the melting zone or during the waning stages of anatexis, and are therefore distally distributed (Shearer et al., 1992; Roda-Robles et al.,1999).

On the basis of field and petrochemical evidence, Mulja et al. (1995b) proposed that the spatial zoning of the Lacorne pegmatites resulted from a combination of sequential melt injection and fracturing of the overlying lithologic units. The earliest beryl pegmatite melt ascended to the pluton carapace via hydraulically-induced fractures created by the fluid-overpressured magma chamber. This melt withdrawal caused contraction of the chamber, thereby creating fractures or reactivating pre-existing fractures, which tapped the more evolved melts in the deeper part of the 
chamber, and emplaced them outward from the pluton. Here, we propose a modification of this model. The Lacorne pegmatites, in contrast to the normally zoned monzogranite pluton, are reversely distributed from the least evolved beryl type within and near the pluton, through the transitional beryl + spodumene type along the margin, to the most evolved spodumene type furthest from the pluton. The pegmatites generally strike NE-SW to E-W, and one pegmatite type does not crosscut another. These structural features imply that the pegmatite field grew laterally by the incremental addition of new dikes along the periphery. While the first melts, being viscous (less mobile) and least evolved (cf. Černý, 1991, 1992), ascended along fractures toward the pluton roof and crystallized rapidly (see section 6.1), the remaining magma continued to differentiate, evolving to a more volatile-rich composition. The early dikes were therefore too rigid for the succeeding, more evolved, lower viscosity beryl + spodumene pegmatite-forming magma to intrude, i.e., the later magma failed to overcome the yield strength of the solidifying or already solidified beryl pegmatites. Thus, the beryl + spodumene pegmatite magma intruded adjacent to and beyond the beryl pegmatites along the periphery of the pluton. This process occurred repeatedly, leading eventually to the emplacement of the most evolved $\left(\mathrm{H}_{2} \mathrm{O}+\mathrm{F}+\right.$ Li-rich), least viscous and most mobile spodumene pegmatite-forming magma furthest from the pluton. An important feature of our revised model is that it does not require the storage of the more evolved magmas, something that Simmons and Webber (2008) considered to be a major weakness of the differentiation model.

\subsection{Comparison to other Be \pm Li-bearing pegmatites}


The observations and data presented in this paper show that the Lacorne rare-element pegmatite-forming magma was saturated with an aqueous fluid pene-contemporaneously with emplacement, and that this fluid contained significant concentrations of dissolved $\mathrm{CO}_{2}$, which exsolved in response to cooling during the late stages of pegmatite crystallization. Even though the internal evolution of many other $\mathrm{Be} \pm \mathrm{Li}$ pegmatites has also been interpreted to involve early exsolution of fluid (e.g., Lu and Lottermoser, 1997; Beurlen et al., 2001; Sirbescu and Nabelek, 2003; and Sirbescu et al., 2008), we do not exclude the possibility that for some pegmatites fluid exsolution occurred later. For example, Alfonso and Melgarejo (2008) and Zhou et al. (2015) cited the absence of fluid inclusions in minerals from the border zone of the Cap de Creus beryl pegmatites, Spain, and the Koktokay pegmatite in northwest China, respectively, as evidence that fluids only began to exsolve during an intermediate stage of pegmatite crystallization.

In many pegmatite bodies, including those at Lacorne, the late stage evolution is characterized by the appearance of $\mathrm{CO}_{2}$. Examples are the Cap de Creus beryl pegmatites referred to above (Alfonso and Megarejo, 2008), the Tin Mountain spodumene + pollucite pegmatite of the Harney Peak granite, South Dakota (Sirbescu and Nabelek, 2003) and the Tanco Li $+\mathrm{Ta}+$ Cs pegmatite (London, 1986; Thomas et al., 1988). Most authors, including ourselves, attribute the origin of the $\mathrm{CO}_{2}$ to exsolution from an aqueous-magmatic fluid and, in the case of Lacorne, we believe that this was induced by cooling. In contrast, London (1986) proposed that at Tanco the $\mathrm{CO}_{2}$ was produced by decomposition of an unidentified carbonate mineral, which was subsequently identified as zabuyelite $\left(\mathrm{Li}_{2} \mathrm{CO}_{3}\right)$ by Anderson et al. (1994). Although carbonate minerals, mainly calcite (zabuyelite is present in spodumene-hosted inclusions), are common in the Lacorne pegmatites, we consider it more likely that they are simply a reflection of the high 
activity of dissolved $\mathrm{CO}_{2}$ in the aqueous phase. Indeed, any calcite that was precipitated at high temperature would have tended to dissolve on cooling because of retrograde solubility (Fein and Walther, 1987, 1989), which may explain why calcite is not part of the pegmatite paragenesis. In principle, however, some $\mathrm{CO}_{2}$ could have been produced by dissolution of zabuyelite, which has prograde solubility.

\section{Summary and Conclusions}

The fluid evolution that was proposed in the preceding paragraphs is illustrated schematically in Figure 13 and started with the emplacement of a pegmatite-forming magma at temperatures between 650 and $550{ }^{\circ} \mathrm{C}$ and a pressure of $3.5 \mathrm{~Kb}$, i.e., within the petalite + liquid field. During crystallization of the beryl pegmatites, this magma was near or at saturation with a low-salinity, $\mathrm{CO}_{2}$-bearing, Na-dominated fluid, containing appreciable Fe. The residual magma became enriched in $\mathrm{Mn}, \mathrm{Li}$ and $\mathrm{Cs}$ and depleted in $\mathrm{Fe}$ in the later crystallizing spodumene pegmatite. Upon emplacement, this last pegmatite-type expelled its exsolved Li-bearing fluid into the host amphibolite where it caused brecciation and induced holmquistite replacement of mafic minerals along the contact. During this interaction, the fluid became enriched in $\mathrm{Ca}$, which probably originated from the altered country rocks. The Ca formed calcic rims on albite, microlite on manganocolumbite, and possibly led to the precipitation of apatite. The beryl-bearing pegmatites underwent at least two major episodes of internal hydraulic fracturing, the first being at the magmatic stage and the second at the magmatic-hydrothermal stage. Both led to a temporary drop in pressure. The second stage marked the beginning of incursions of Ca-rich solutions into the pegmatites. Although the origin of these fluids has yet to be determined, they probably represent a

Mulja, T. and A. E. Williams-Jones. "The Physical and Chemical Evolution of Fluids in 
mixture of fluids exsolved from the pegmatite melts and connate waters, which were subsequently trapped as high Ca Type $1 \mathrm{~b}$ fluid inclusions. The final event in the evolution of the pegmatite-hosted fluids was the separation of the magmatic fluid into aqueous and $\mathrm{CO}_{2}$ phases and their heterogeneous entrapment in late quartz at a temperature between 250 and $350{ }^{\circ} \mathrm{C}$.

In summary, the results of this study indicate, at least for the case of boron- and phosphorous-poor rare element pegmatites, such as those at Lacorne, that aqueous phase saturation can take place at an early stage of rare element pegmatite crystallization, and that the pegmatite evolution is matched by the evolution of the solute chemistry of the exsolving aqueous fluid. The regional zonation of the Lacorne rare-element pegmatites is explained by the evolution of the magma to higher contents of volatiles $\left(\mathrm{H}_{2} \mathrm{O}, \mathrm{F}\right.$ and $\left.\mathrm{Li}\right)$ and progressively lower viscosity, which promoted the intrusion of the later forming pegmatite types adjacent to and beyond the more viscous early beryl pegmatites in the less competent amphibolites that host the Lacorne pluton.

\section{Acknowledgement}

The research described here was funded by grants from the Natural Sciences and Engineering Research Council of Canada (NSERC) and the Fonds de recherche du Québec nature et technologies (FQRNT). Anne Préfontaine provided some fluid inclusion data and SEM photographs of opened fluid inclusions. Iain Samson, University of Windsor, helped with the crush-leach analyses and Stephanne Brienne the Raman spectroscopic analyses. Insightful reviews by the late Edwin Roedder, David Vanko, Ilya Veksler and David London of an earlier manuscript on the same subject and discussions with Scott Wood, Robert Martin and Jeremy 
Fein are gratefully acknowledged. Comments by three anonymous referees helped us to improve the current manuscript significantly. 


\section{References}

Alfonso, P., Melgarejo, J.C., 2008. Fluid evolution in the zoned rare-element pegmatite field at Cap de Creus, Catalonia, Spain. Can. Mineral. 46, 597-617.

Angus, S., Armstrong, B., deReuck K.M., Altunin V.V., Gadetskii O.G., Chapela G.A., Rowlinson J.S., 1976. International thermodynamic tables of the fluid state, vol. 3 Carbon dioxide. Pergamon Press, Oxford, England.

Anderson, A.J., Clark, A.H., Harrison, F., Bodnar, R.J., 1994. Zabuyelite (Li2 $\left.\mathrm{CO}_{3}\right)$ in spodumene-bearing pegmatites. Geol. Mineral. Assoc. Can. Programs with abstracts. 19, A3.

Baker, D.B., 1998. The escape of pegmatite dikes from granitic pluton: constraints from new models of viscosity and dike propagation. Can. Mineral. 36, 255-263.

Bakker, R.J., Jansen, J.B.H., 1994. A mechanism for preferential $\mathrm{H}_{2} \mathrm{O}$ leakage from fluid inclusions in quartz, based on TEM observations. Contrib. Mineral. Petrol. 116, 7-20.

Bartels, A., Behrens, H., Holtz, F., Schmidt, B.C., Fechtelkord, M., Knipping, J., Crede, L., Baasner, A., Pukallus, N., 2013. The effect of fluorine, boron and phosphorus on the viscosity of pegmatitic liquids. Chem. Geol. 346, 184-198.

Bartels, A., Behrens, H., Holtz, F., Schmidt, B.C., 2014. The effect of lithium on the viscosity of pegmatite forming liquids. Chem. Geol. 410, 1-11.

Behrens, H., Gaillard, F., 2006. Geochemical aspects of melts: Volatiles and redox behavior. Elements 2, 275-280.

Beurlen, H., da Silva, M.R.R., de Castro, C., 2001. Fluid inclusion microthermometry in Be-Ta-(Li-Sn)-bearing pegmatites from the Borborema Province, Northeast Brazil. Chem. Geol. 173, 107-123.

Blake, S., 1981. Eruptions from zoned magma chambers. J. Geol. Soc. 138, 281-287.

Blanchet, D., and six others, 2012. Feasibility Study Update NI 43-101 Technical Report Quebec Lithium Project La Corne Township, Quebec. Canadian Lithium Corp.

Bodnar, R.J., 1983. A method of calculating fluid inclusion volumes based on vapor bubble diameters and P-V-T-X properties of fluid inclusions. Econ. Geol. 78, 535-542.

Bodnar, R.J., 1993. Revised equation and table for determining the freezing point depression of $\mathrm{H}_{2} \mathrm{O}-\mathrm{NaCl}$ solutions. Geochim. Cosmochim. Acta 57, 683-684. 
Bottinga, Y., Javoy, M., 1975. Oxygen isotope partitioning among the minerals in igneous and metamorphic rocks. Rev. Geophysi. Space Phys. 13, 401-418.

Bowers, T.S., Helgeson H.C., 1983. Calculation of thermodynamic and geochemical consequences of on ideal mixing in the system $\mathrm{H}_{2} \mathrm{O}-\mathrm{CO}_{2}-\mathrm{NaCl}$ on phase relations in geologic systems: equation state for the $\mathrm{H}_{2} \mathrm{O}-\mathrm{CO}_{2}-\mathrm{NaCl}$ fluids at high pressures and temperatures. Geochim. Cosmochim. Acta 47, 1247-1275.

Brisbin, W.C., 1986. Mechanics of pegmatite intrusion. Am. Mineral.71, 644-651.

Brown, P.E., 1998. Fluid inclusion modeling for hydrothermal systems, in: Richards, J.P., Larson, P.B. (Eds.), Techniques in hydrothermal ore deposits geology, Rev. Econ. Geol. 10, 151-171.

Brown, P.E., Lamb, W.M., 1989. P-V-T properties of fluids in the system $\mathrm{H}_{2} \mathrm{O} \pm \mathrm{CO}_{2} \pm \mathrm{NaCl}$ : new graphical presentations and implications for fluid inclusion studies. Geochim. Cosmochim. Acta 53, 1209-1221.

Černý, P., 1991. Rare-element granitic pegmatites. Part II: Regional to global environments and petrogenesis, Geosci. Can. 18, 68-81.

Černý, P., 1992. Regional zoning of pegmatite populations and its interpretation. Mitt. Öster. Mineral. Gesell. 137, 99-107.

Clayton R.N., O'Neil, J.R., Mayeda, T.K., 1972. Oxygen isotope exchange between quartz and water. J. Geophys. Res. 77, 3057-3067.

Clemens, J. D., Mawer, C.K., 1992. Granitic magma transport by fracture propagation. Tectonophysics 204, 339-360.

Darling, R.S., 1991. An extended equation to calculate $\mathrm{NaCl}$ contents from final clathrate melting temperatures in $\mathrm{H}_{2} \mathrm{O}-\mathrm{CO}_{2}-\mathrm{NaCl}$ fluid inclusions: implications for $\mathrm{P}-\mathrm{T}$ isochore location. Geochim. Cosmochim. Acta 55, 3869-3871.

Davis, D.W., Lowenstein, T.K., Spencer, R.J., 1990. Melting behavior of fluid inclusions in laboratory-grown halite crystals in the systems $\mathrm{NaCl}-\mathrm{H}_{2} \mathrm{O}, \mathrm{NaCl}-\mathrm{KCl}-\mathrm{H}_{2} \mathrm{O}$, $\mathrm{NaCl}-\mathrm{MgCl}_{2}-\mathrm{H}_{2} \mathrm{O}$, and NaCl-CaCl $2-\mathrm{H}_{2} \mathrm{O}$. Geochim. Cosmochim. Acta 54, 591-601.

Dawson, K.R., 1966. A comprehensive study of the Preissac-Lacorne batholith, Abitibi county, Québec. Geol. Surv. Can. Bull. 142. 
Drebushchak, V., Ogienko, A., Yunoshev, A.S., 2016. Metastable eutectic melting in the $\mathrm{NaCl}-\mathrm{H}_{2} \mathrm{O}$ system. Thermochimica Acta 647, 94-100.

Derry, D.R., 1950. Lithium-bearing pegmatites in northern Quebec. Econ. Geol. 45, 95-104.

Dubois, M., Monnin, C., Castelain, T., Coquinot, Y., Guoy, S., Gauthier, A., Goffe, B., 2013. Investigation of the $\mathrm{H}_{2} \mathrm{O}-\mathrm{NaCl}-\mathrm{LiCl}$ system: a synthetic fluid inclusion study and thermodynamic modeling from $-50^{\circ}$ to $+100^{\circ} \mathrm{C}$ and up to $12 \mathrm{~mol} / \mathrm{kg}$. Econ. Geol. $105,329-338$.

Ducharme, Y., Stevenson, R.K., Machado, N.1997. Sm/Nd geochemistry and U-Pb geochronology of the Preissac and Lamotte leucogranites, Abitibi Subprovince. Can. J. Earth Sci. 34, 1059-1071.

Engvik, A.K., Bertram, A., Kalthoff, J., Stöckhert, B., Austrheim, H., Elvevold, S., 2005.

Magma-driven hydraulic fracturing and infiltration of fluids into the damaged host rock, an example from Dronning Maud Land, Antarctica. J. Struct. Geol. 27, 839-854.

Evensen, J.M., London, D., Wendlandt, R.F., 1999. Solubility and stability of beryl in granitic melts. Am. Mineral. 84, 733-745.

Fein, J.B., Walther J.V., 1987. Calcite solubility in supercritical $\mathrm{CO}_{2}-\mathrm{H}_{2} \mathrm{O}$ fluids. Geochim. Cosmochim. Acta 51, 1665-1673.

Fein, J.B., Walther J.V., 1989. Calcite solubility and speciation in supercritical $\mathrm{NaCl}-\mathrm{HCl}$ aqueous fluids. Contrib. Mineral. Petrol. 103, 317-324.

Feng, R., Kerrich, R., 1990. Geobarometry, differential block movements, and crustal structure of the southwestern Abitibi greenstone belt, Canada. Geol. 18, 870-873.

Feng, R., Kerrich, R., McBride, S., Farrar, E., 1992. ${ }^{40} \mathrm{Ar} /{ }^{39} \mathrm{Ar}$ age constraints on the thermal history of the Archean Abitibi greenstone belt and the Pontiac Subprovince: implications for terrane collision, differential uplift, and overprinting of gold deposits. Can. J. Earth Sci. 29, 1389-1411.

Fuertes-Fuente, M., Martin-Izard, A., Boiron, M.C., Viñuela, J.M., 2000. P-T Path and fluid evolution in the Franqueira granitic pegmatite, central Galicia, Northwestern Spain. Can. Mineral. 38, 1163-1175.

Gammel, E.M., Nabelek, P.I., 2016. Fluid inclusion examination of the transition from 
magmatic to hydrothermal conditions in pegmatites from San Diego County, California. Am. Mineral. 101,1906-1915.

Heinrich, E.Wm., 1953. Zoning in pegmatite districts. Am. Mineral. 38, 68-87.

Heyen, G., Ramoz C., Dubessy, A., 1982. Simulation des equilibres de phases dans le systeme $\mathrm{CO}_{2}-\mathrm{CH}_{4}$ en dessous de $50^{\circ} \mathrm{C}$ et de 100 bar. Application aux inclusions fluides. C. R. Acad. Sci. Paris 294, 203-206.

Hildreth, W., Wilson, C.J.N., 2007. Compositional zoning of the Bishop Tuff. J. Petrol. 48, 951-999.

Hulsbosch , N., Hertogen, J., Dewaele, S., Andre, L., Muchez, P., 2014. Alkali metal and rare earth element evolution of rock-forming minerals from the Gatumba area pegmatites (Rwanda): Quantitative assessment of crystal-melt fractionation in the regional zonation of pegmatite groups. Geochim. Cosmochim. Acta 132, 349-374.

Jahns, R.H, Tuttle, O.F., 1963. Layered pegmatite-aplite intrusives. Min. Soc. Am. SP. 1. 92p.

Johannes, W., Holtz, F., 1991. Formation and ascent of granitic magmas. Geologische Rundschau 80, 225-231.

Li, J., Chou, I-M., 2017. Homogenization experiments of crystal-rich inclusions in spodumene from Jiajika Lithium deposit, China, under elevated external pressure in a hydrothermal diamond-anvil cell. Geofluids (Hindawi) 2017, 1-12.

London, D., 1984. Experimental phase equilibria in the system $\mathrm{LiAlSiO}_{4}-\mathrm{SiO}_{2}-\mathrm{H}_{2} \mathrm{O}$ : a petrogenetic grid for lithium-rich pegmatites. Am. Mineral. 69, 995-1004.

London, D., 1986. Magmatic-hydrothermal evolution in the Tanco rare element pegmatite: evidence from fluid inclusions and phase equilibrium experiments. Am. Mineral. 71, 376-395.

London, D., 1992. The application of experimental petrology to the genesis and crystallization of granitic pegmatites. Can. Mineral. 30, 499-540.

London, D., 2005. Granite pegmatites: an assessment of current concepts and directions for the future. Lithos 80, 281-303.

London, D., 2009. The origin of primary textures in granitic pegmatites. Can. Mineral. 47, $697-724$. 
London, D., 2014. A petrologic assessment of internal zonation in granitic pegmatites. Lithos 184, 74-104.

Lowenstern, J.B., 1995. Intrusive degassing at the magma/wall rock interface, in: Brown, M., Picolli, P.M. (Eds.), The Origin of Granites and Related Rocks: Third Hutton Symposium: Abstracts ,USGS Circular 1129, p. 92.

Lu, J., Lottermoser B.G., 1997. Petrogenesis of rare-element pegmatites in the Olary Block, South Australia, part 2. Fluid inclusion study. Mineral. Petrol. 59, 21-41.

Matthews, S.J., Sparks, R. S. J., Gardeweg, M. C., 1999. The Piedras Grandes-Soncor Eruptions, Lascar Volcano, Chile; Evolution of a Zoned Magma Chamber in the Central Andean Upper Crust. J. Petrol. 40, 1891-1919.

Mulja, T., Williams-Jones, A.E., Wood, S.A., Boily, M., 1995a. The rare-element monzogranite-pegmatite systems in the Preissac-Lacorne batholith, Quebec: I. Geology and mineralogy. Can. Mineral. 33, 793-832.

Mulja, T., Williams-Jones, A.E., Wood, S.A., Boily M., 1995b. The rare-element monzogranite-pegmatite systems in the Preissac-Lacorne batholith, Quebec: II. Geochemistry and Petrogenesis. Can. Mineral. 33, 817-833.

Mulja, T., Williams-Jones A.E., Martin R.F., Wood S.A., 1996. Compositional variation and structural state of $\mathrm{Nb}-\mathrm{Ta}$ oxide minerals in rare-element granitic pegmatites from the Preissac-Lacorne batholith, Quebec. Am. Mineral. 81, 146-157.

Nabelek, P.I., Whittington, A.G., Sirbescu, M-LC., 2010. The role of $\mathrm{H}_{2} \mathrm{O}$ in rapid emplacement and crystallization of granite pegmatites: resolving the paradox of large crystals in highly undercooled melts, Contrib. Mineral. Petrol. 160, 313-325.

Oakes, C.S., Bodnar R.J., Simonson, J.M., 1990. The system NaCl- $\mathrm{CaCl}_{2}-\mathrm{H}_{2} \mathrm{O}$ : I. The ice liquidus at $1 \mathrm{~atm}$ total pressure. Geochim. Cosmochim. Acta 54, 603-610.

Palinkaš, S.S., Wegner, R., Čobić, A., Palinkaš, LA., Barreto, S.B., Váczi T., Bermanec, V., 2014. The role of magmatic and hydrothermal processes in the evolution of Be-bearing pegmatites: Evidence from beryl and its breakdown products. Am. Mineral. 99, 424-432. Powell, W.G., 1994. A petrological and geochronological study of the metamorphic history of the Rouyn-Noranda area, Quebec. Unpublished Ph.D thesis, Queen's University, Kingston, 
Ontario.

Powell, W.G., Hodgson, C.J., Hanes, J.A., Carmichael, D.M., McBride, S., Farrar, E., 1995. ${ }^{40} \mathrm{Ar} /{ }^{39} \mathrm{Ar}$ geochronological evidence for multiple postmetamorphic hydrothermal events focused along faults in the southern Abitibi greenstone belt. Can. J. Earth Sci. 32, 768-786 Roedder, E., 1984. Fluid inclusions; Rev. Mineral. 12, MSA.

Roda-Robles, E., Pesquera, A., Velasco, F., Fontan, F., 1999. The granitic pegmatites of the Fregeneda area (Salamanca, Spain): characteristics and petrogenesis. Mineral. Mag. 63, $535-556$.

Selway, J.B., Novak, M., Hawthorne, F.C., Cerny, P., Ottolini, L., Kyser, T.K., 1998.

Rossmanite, , []( $\left.\mathrm{LiAl}_{2}\right) \mathrm{Al}_{6}\left(\mathrm{Si}_{6} \mathrm{O}_{8}\right)\left(\mathrm{BO}_{3}\right)_{3}(\mathrm{OH})_{4}$, a new alkali-deficient tourmaline:

Description and crystal structure. Am Mineral. 83, 896-100.

Sibson, R.H., 1994, Crustal stress, faulting, and fluid flow, in: Parnel, J., (Ed.): Geofluids: origin, migration and evolution of fluids in sedimentary basins. Sp. Pub. Geol. Soc. London 78, 69-84.

Shearer C.K., Pipike, J.J., Jolliff, B.F., 1992. Petrogenetic links among granites and pegmatites in the Harney Peak rare-element granite-pegmatite system, Black Hills, South Dakota. Can Mineral. 30,785-80.

Simmons, W.B., Webber, K.I., 2008. Pegmatite genesis: state of the art. Eur. J. Mineral. 20, $421-438$.

Sirbescu, M-L.C., 2017. Comparative fluid chemistry of internally-zoned pegmatites. NGF Abstracts and Proceedings 2, 131-134.

Sirbescu, M-L.C., Nabelek, P.I., 2003. Crystallization conditions and evolution of magmatic fluids in the Harney Peak Granite and associated pegmatites, Black Hills, South Dakota-Evidence from fluid inclusion. Geochim. Cosmochim. Acta 67, 2443-2465.

Sirbescu, M-L.C., Hartwick, E.E., Student, J.J., 2008. Rapid crystallization of the Animikie Red Ace Pegmatite, Florence county, northeastern Wisconsin: inclusion microthermometry and conductive-cooling modeling. Contrib. Mineral. Petrol. 156, 289-305.

Sirbescu, M-L.C., Schmidt, C., Veksler, I.V., Whittington, A.G., Wilke, M., 2017. Experimental Crystallization of undercooled felsic liquids: generation of pegmatitic texture. J. Petrol., 58, 
$539-568$.

Smirnov, S.Z., 2015. The fluid regime of crystallization of water-saturated granitic and pegmatitic magmas: a physicochemical analysis. Russian Geol. Geophys. 56, 1292-1307.

Sterner, S.M., Hall, D.L., Bodnar, R.J., 1988. Synthetic fluid inclusions. V. Solubility relations in the system $\mathrm{NaCl}-\mathrm{KCl}-\mathrm{H}_{2} \mathrm{O}$ under vapor-saturated conditions. Geochim. Cosmochim. Acta $52,989-1005$.

Taner, H., Williams-Jones, A.E., Wood, S.A., 1998. The nature and origin and physicochemical controls of hydrothermal Mo-Bi mineralization in the Cadillac deposit, Quebec, Canada. Mineral. Deposita 33, 579-590.

Taylor, H. P., Sheppard, S.M.F., 1986. Igneous rocks: I. Processes of isotopic fractionation and isotope systematics, in: Valley, J.W., Taylor, H.P., O'Neil, J.R. (Eds.): Stable Isotopes in High Temperature Geological Processes, Mineral. Soc. Am. Washington, pp. 227-271. Thomas, A.V., Bray C.J., Spooner E.T.C., 1988. A discussion of the Jahns-Burnham proposal for the formation of zoned granitic pegmatites using solid-liquid-vapour inclusions from the Tanco pegmatite, S.E. Manitoba, Canada. Trans. Royal Soc. Edin. Earth Sci. 79, 299-315. Thomas, R., Davidson, P., 2016. Revisiting complete miscibility between silicate melts and hydrous fluids, and the extreme enrichment of some elements in the supercritical state Consequences for the formation of pegmatites and ore deposits. Ore Geol. Rev. 72, $1088-1101$.

Thomas, R., Davidson, P., Beurlen, H., 2012. The competing models for the origin and internal evolution of granitic pegmatites in the light of melt and fluid inclusion research. Mineral. Petrol. 106, 55-73.

Thomas, R., Webster, J.D., Heinrich, W., 2000. Melt inclusions in pegmatite quartz: complete miscibility between silicate melts and hydrous fluids at low pressure. Contrib. Mineral. Petrol. 139, 394-401.

Thomas, R., Davidson, P., Badanina, E., 2009. A melt and fluid inclusion assemblage in beryl from pegmatite in the Orlovka amazonite granite, East Transbaikalia, Russia: implications for pegmatite-forming melt systems. Mineral. Petrol. 96, 129-140.

Tindle, A.G., Breaks, F.W., Selway, J.B., 2002. Tourmaline in petalite-subtype granitic 
pegmatites: evidence of fractionation and contamination from the Pakeagama Lake and Separation Lake areas of NW Ontario, Canada. Can. Mineral. 40, 753-788.

Tuttle, O.F., Bowen N.L., 1958. Origin of granite in the light of experimental studies in the system $\mathrm{NaAlSi}_{3} \mathrm{O}_{8}-\mathrm{KAlSi}_{3} \mathrm{O}_{8}-\mathrm{SiO}_{2}-\mathrm{H}_{2} \mathrm{O}$. Geol. Soc. Am. Memoir 74.

Vasyukova, O.V., Williams-Jones, A.E., Blamey, N.J.F., 2016. Fluid evolution in the Strange Lake granitic pluton, Canada: Implications for HFSE mobilisation. Chem. Geol. 444, 83-100.

Vityk, M.O., Bodnar, R.J., Dudok, I.V., 1995. Natural and synthetic re-equilibration textures of fluid inclusions in quartz (Marmarosh Diamonds): Evidence for refilling under conditions of compressive loading. Eur. J. Mineral. 7, 1071-1087.

Watanabe, S., Widom, E., Ui, T., Miyaji, N., Roberts, A. M., 2006. The evolution of a chemically zoned magma chamber: The 1707 eruption of Fuji volcano, Japan. J. Volc. Geotherm. Res. 152, 1-19.

Webber, K.L., Simmons, Wm.B., Falster, A.U., Foord, E.E., 1999. Cooling rates and crystallization dynamics of shallow level pegmatite-aplite dikes, San Diego County, California. Am. Mineral. 84, 708-717.

Werre, R.W.Jr., Bodnar R.J., Bethke P.M., Barton Jr, P.B., 1979. A novel gas-flow fluid inclusion heating/freezing stage (Abstr.). Geol. Soc. Am. Abstrc. Progs. 11, 539.

Wood, S.A., Williams-Jones, A.E., 1993. Theoretical studies of the alteration of spodumene, petalite, eucryptite and pollucite in granitic pegmatites: exchange reactions with alkali feldspars. Contrib. Mineral. Petrol. 114, 255-263.

Wyllie, P., Tuttle, O. F., 1964. Experimental investigation of silicate systems containing two volatile components. III. The effects of $\mathrm{SO}_{3}, \mathrm{P}_{2} \mathrm{O}_{5}, \mathrm{HCl}$ and $\mathrm{Li}_{2} \mathrm{O}$, in addition to $\mathrm{H}_{2} \mathrm{O}$, on the melting temperatures of albite and granite. Am. J. Sci. 262, 930-939.

Yang, X-M., 2017. Estimation of crystallization pressure of granite intrusions. Lithos 286, 324-329.

Zhou, Q.F., Qin, K.Z., Tang, D.M., Wang, C.L., Tian, Y.E., Sakyi, P.A., 2015. Mineralogy of the Koktokay No. 3 pegmatite, Altai, NW China: implications for evolution and melt-fluid processes of rare-metal pegmatites. Eur. J. Mineral. 27, 433-457. 
Mulja, T. and A. E. Williams-Jones. "The Physical and Chemical Evolution of Fluids in Rare-Element Granitic Pegmatites Associated with the Lacorne Pluton, Quebec, Canada." Chemical Geology 493 (Aug 20 2018): 281-97. http://dx.doi.org/10.1016/j.chemgeo.2018.06.004. 


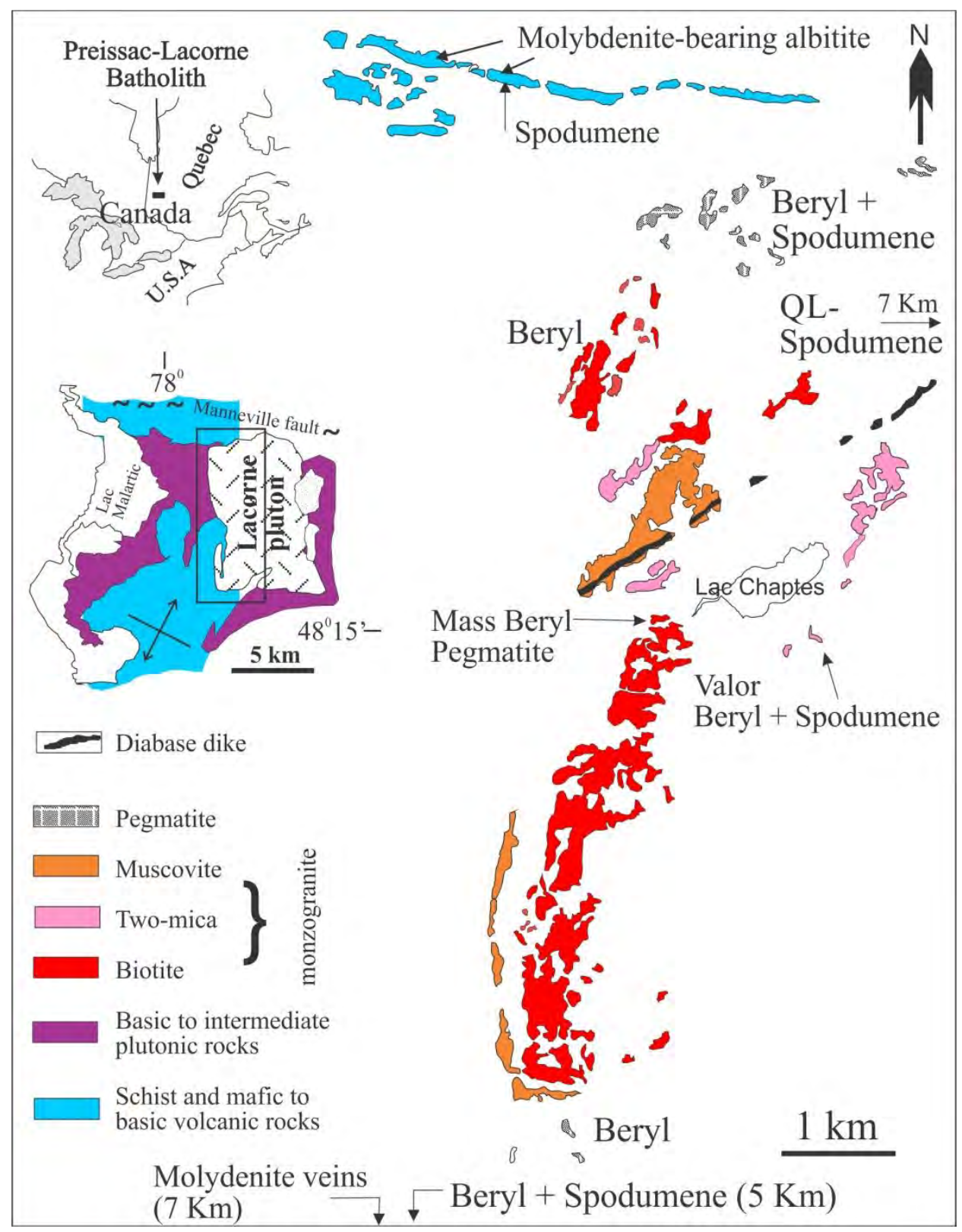

Fig. 1. Location and geological map of the Lacorne pluton and associated rare-element pegmatites in the eastern part of the Preissac-Lacorne batholith, Québec (after Mulja et al., 1996). The three sample locations are MBP (Mass beryl prospect), Valor, and QL (Québec lithium deposit), which is about $7 \mathrm{~km}$ east of the map border. In the north the spodumene pegmatites are small and altered, and hence were excluded in this study. In the south, a swarm of beryl + spodumene pegmatites is located about $5 \mathrm{~km}$ from the margin of the pluton, followed by molybdenite-bearing quartz veins. 


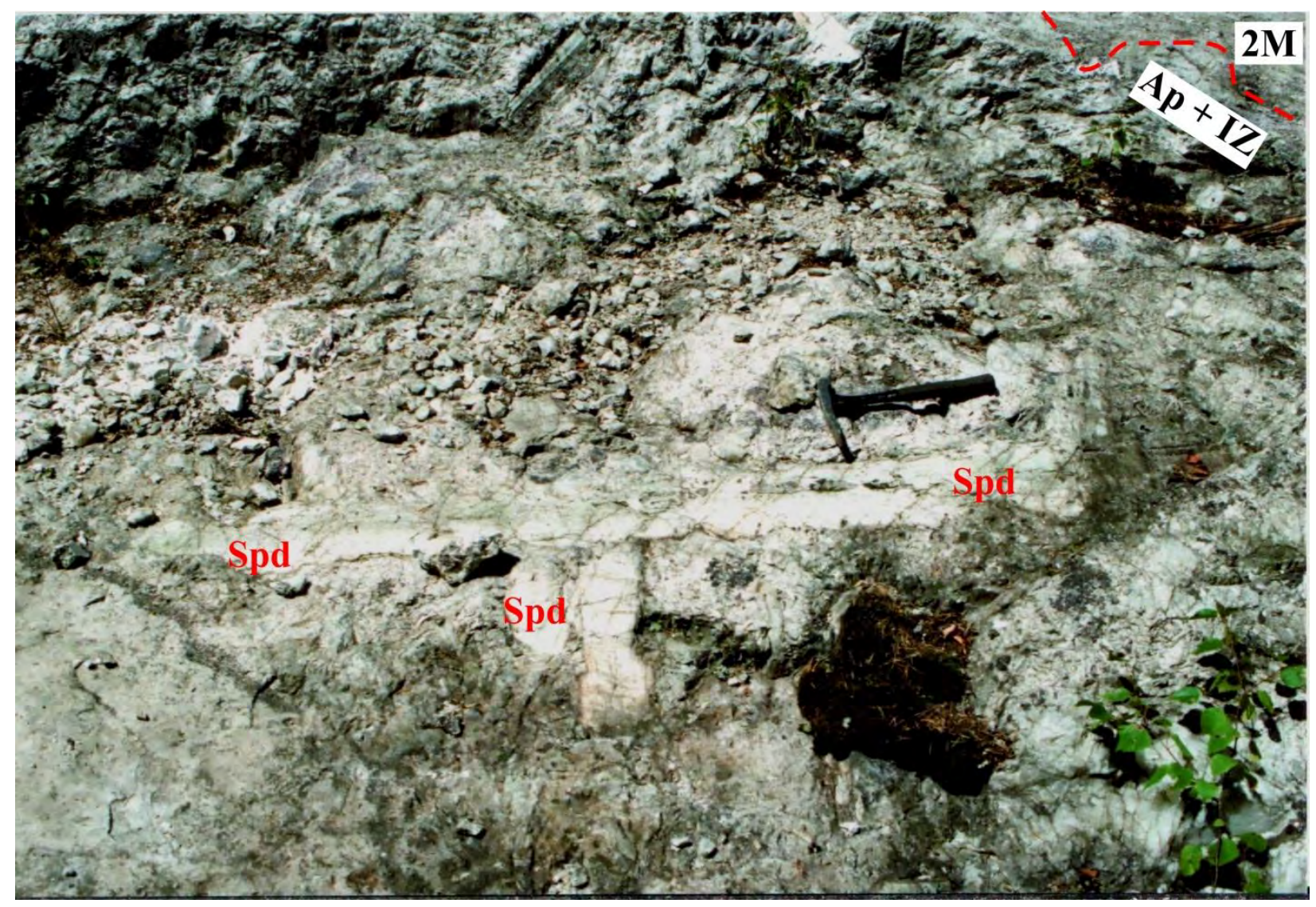

Fig. 2 The Valor beryl + spodumene pegmatite showing a corrugated contact between its aplite border zone with the Lacorne two-mica monzogranite $(2 \mathrm{M})$. The narrow aplite is discontinuous and grades into the intermediate zone (IZ; see Fig. 3 for detail). Spodumene crystals measuring up to $20 \mathrm{~cm} \times 2 \mathrm{~m}$ spanning from the intermediate zone to the core of the Valor $\mathrm{Brl}+\mathrm{Spd}$ pegmatite and displaying a unidirectional solidification texture (UST). The longest spodumene, which appears to cut two shorter crystals, is roughly perpendicular to the contact with the Lacorne two-mica monzogranite. This cross-cutting relationship between the spodumene crystals indicates a crude simultaneous formation of the intermediate zone and the core. 


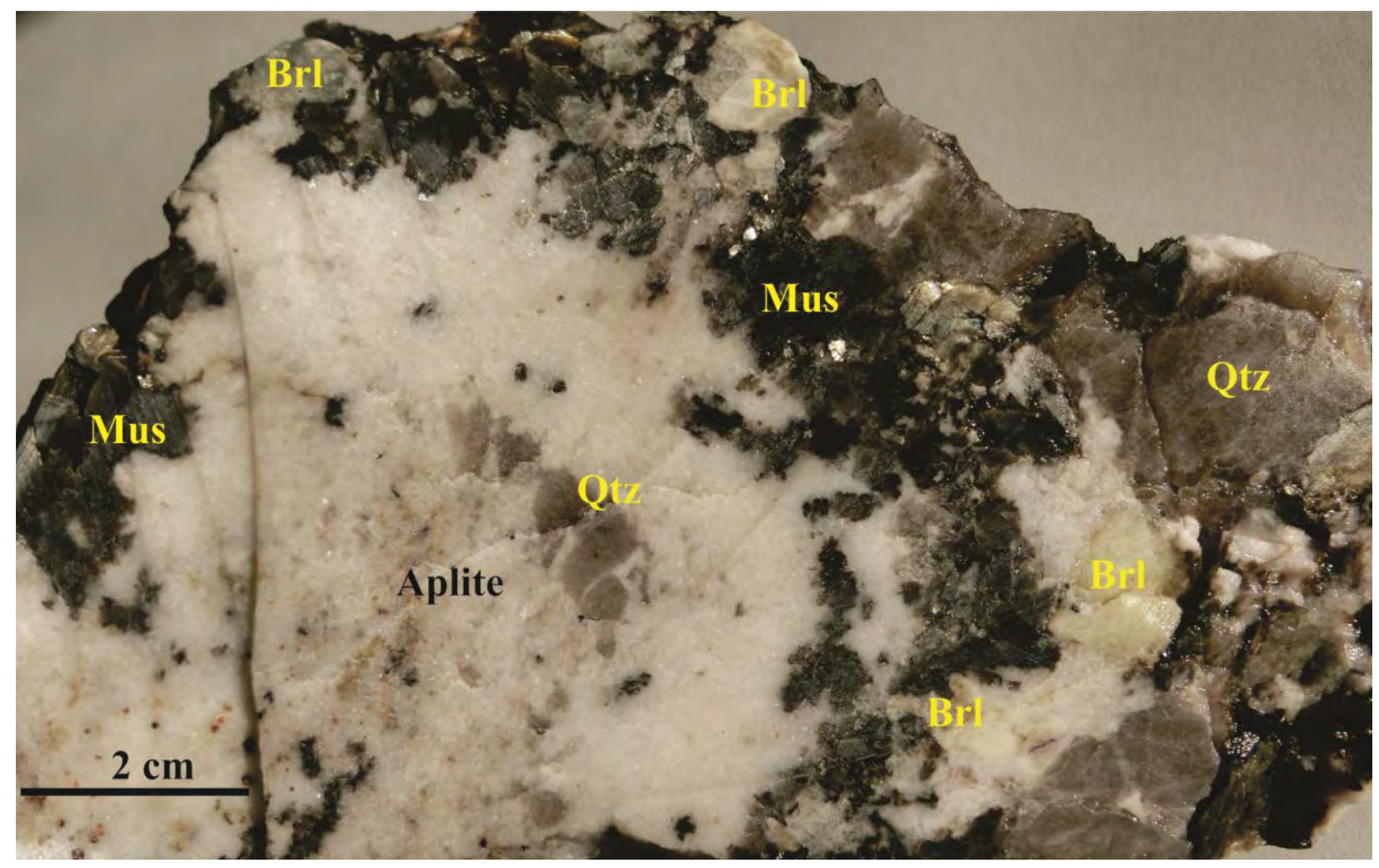

Fig.3 A closed-up photograph of the Valor beryl + spodumene pegmatite showing a corrugated aplite border zone in gradual transition to the intermediate zone that is teemed with books of coarse-grained muscovite and relatively small beryl. 

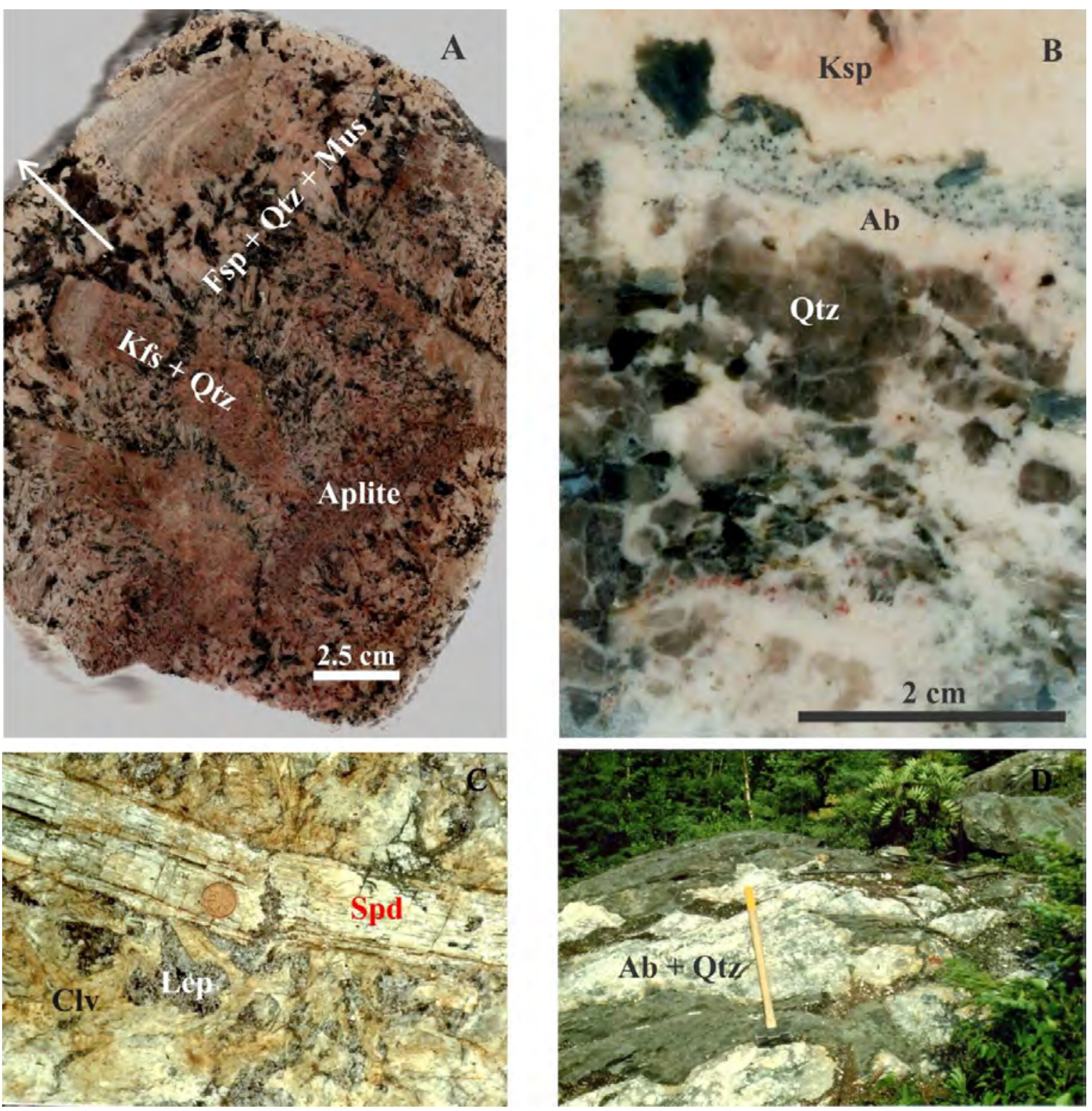

Fig. 4. A). A brecciated beryl pegmatite with fragments of K-feldspar (Kfs) with interstitial aplite and coarse-grained feldspars (Fsp) + quartz + muscovite (Mus) assemblage. The basal graphic texture of the Kfeldspar abruptly transitions into a stack of pink and white bands. The arrow indicates upright position of the pegmatite. B). A brecciated beryl pegmatite with albite infilling the interstices and rimming K-feldspar. Also present are trains of garnet crystals (black grains) along the albitized Ksp margin. C). Brecciated and altered core of beryl + spodumene pegmatite at the Valor prospect. The alteration consists of clusters of lepidolite (Lep) and rosette cleavelandite (Clv; low temperature variant of albite). Canadian penny is $2.55 \mathrm{~cm}$ across. D). Brecciated amphibolite overlying the spodumene pegmatites in the Québec lithium area. The breccias are cemented by albite and quartz. Slivers of holmquistite (Li-amphibole) replacing mafic minerals of the amphibolite at the contact with the albite + quartz rock. 

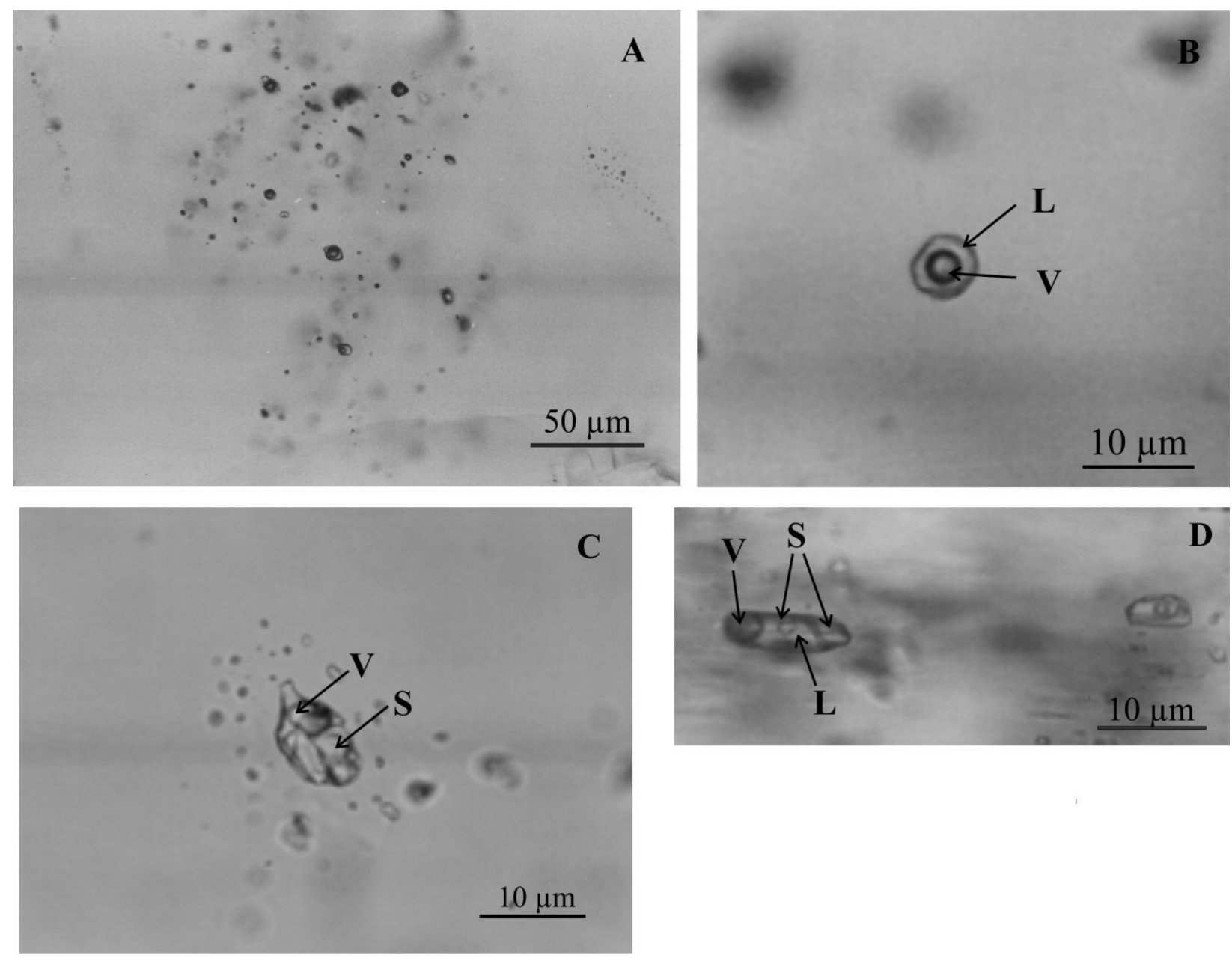

Fig. 5 A) Fluid inclusion assemblage in beryl from beryl pegmatite showing mainly Type 1a L-V inclusions. B) An isolated Type 1a (L-V) inclusion in beryl (beryl pegmatite) consisting of liquid (L) and vapor (V). C) A multi-solid-bearing Type 2 ( $\mathrm{L}-\mathrm{V}-\mathrm{S})$ inclusion in beryl (beryl + spodumene pegmatite). The tiny specks surrounding the inclusion constitute an implosion halo resulting from isobaric cooling (see text). D). Tubular Type 2 inclusions oriented parallel to the c-axis of the host spodumene in a spodumene pegmatite. 


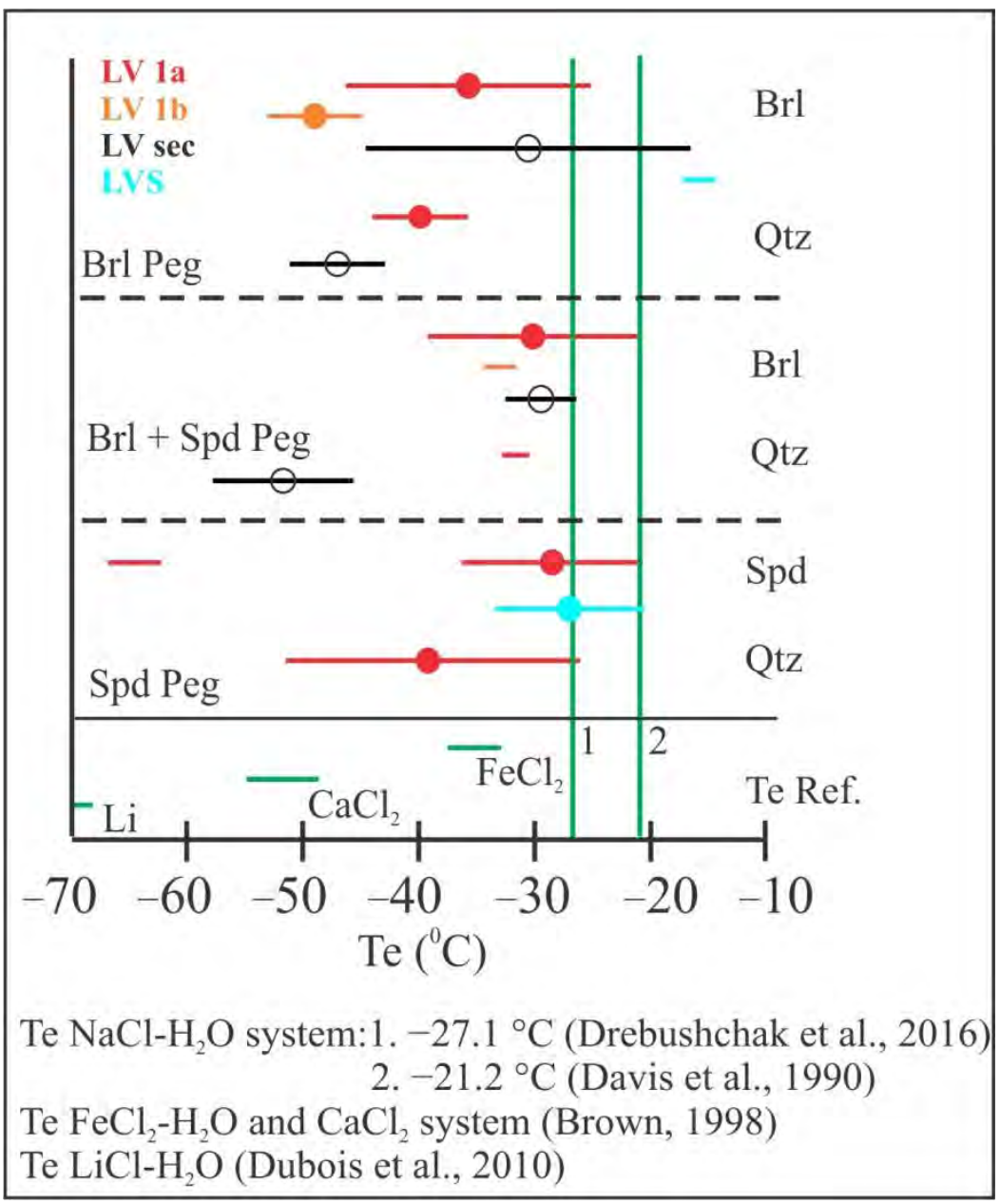

Fig. 6 Initial melting temperatures of ice (Te) in the different types of fluid inclusions in beryl, beryl + spodumene and spodumene pegmatite. Ref.: references 


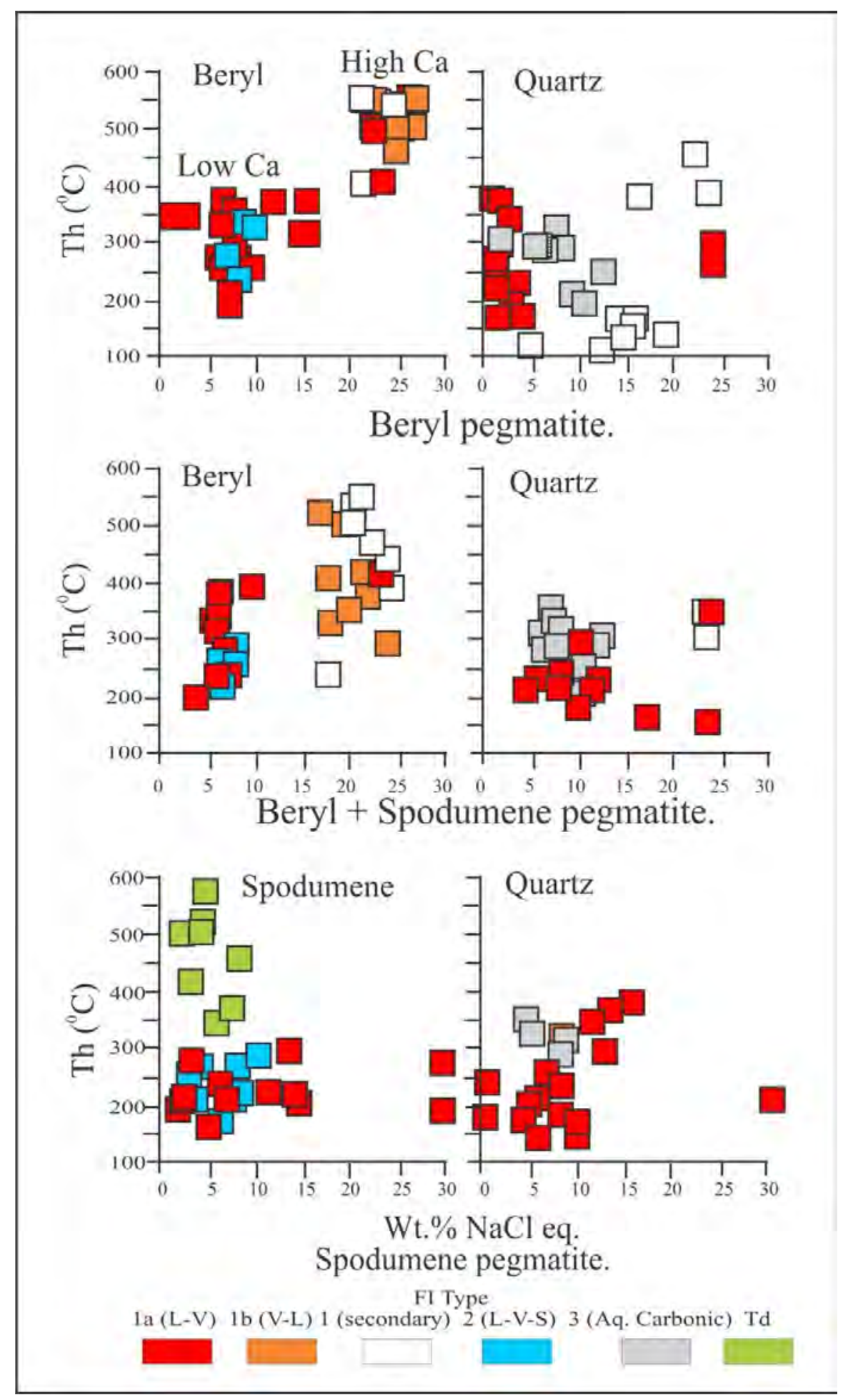

Fig. 7 Homogenization vs. salinity of all fluid inclusion types in beryl, spodumene and quartz from beryl, beryl + spodumene and spodumene pegmatites. 


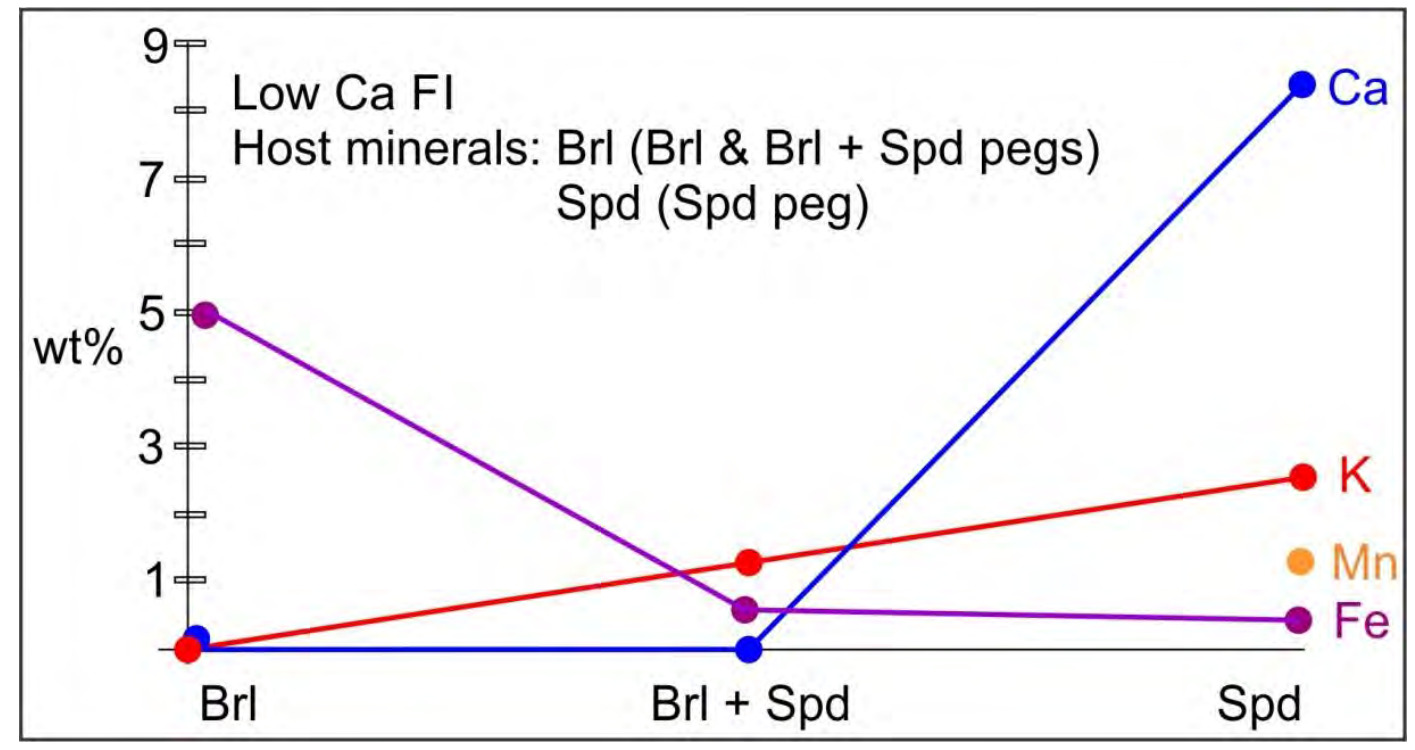

Fig. 8 Compositional variation of cations from decrepitated fluid inclusions in beryl and spodumene from all pegmatite types. These cations are from low Ca population which is likely related to primary fluid inclusions.

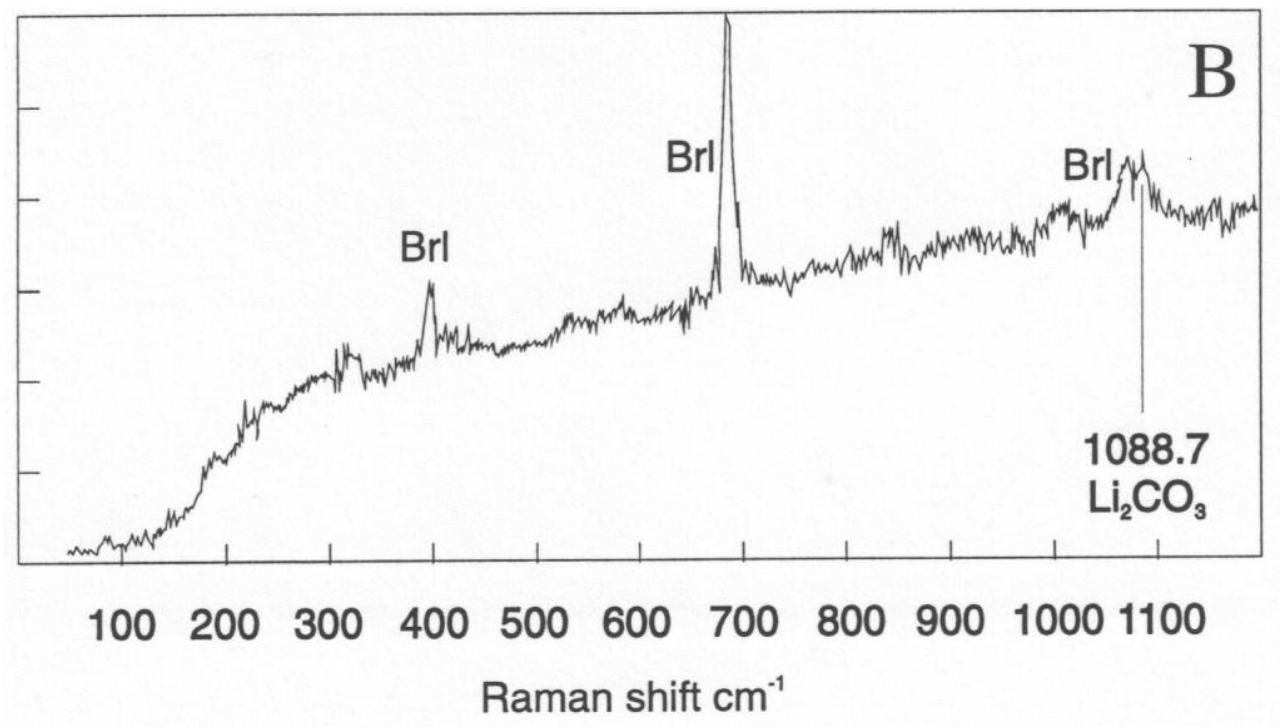

Fig.9 Raman spectrum of birefringent solid in Type 2 fluid inclusion (Fig. 5C), suspected to be Zabuyelite $\left(\mathrm{Li}_{2} \mathrm{CO}_{3}\right)$. 


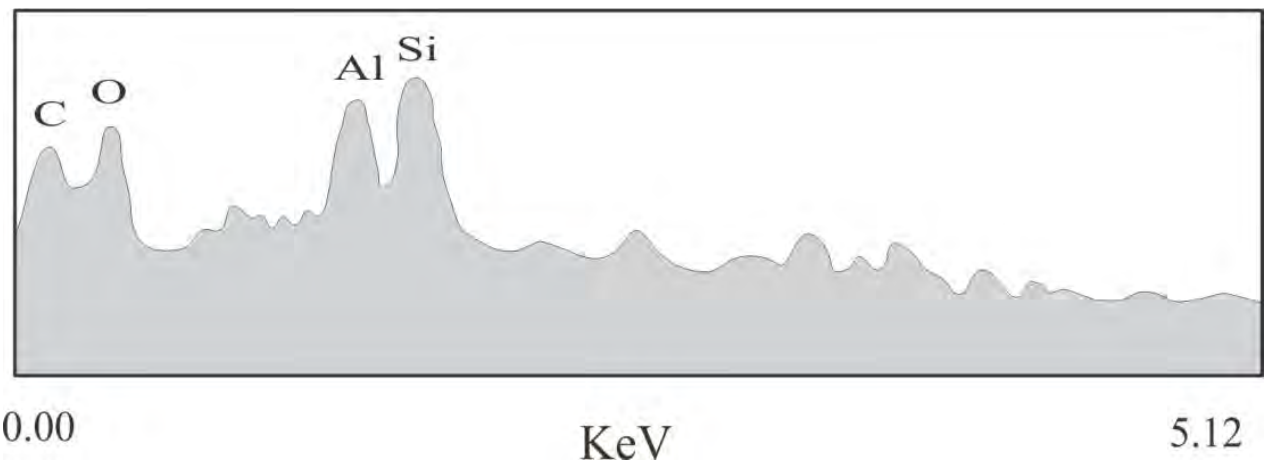

Fig. 10. An EDS-SEM spectrum of a carbonate mineral that may be zabuyelite $\left(\mathrm{Li}_{2} \mathrm{CO}_{3}\right)$. 

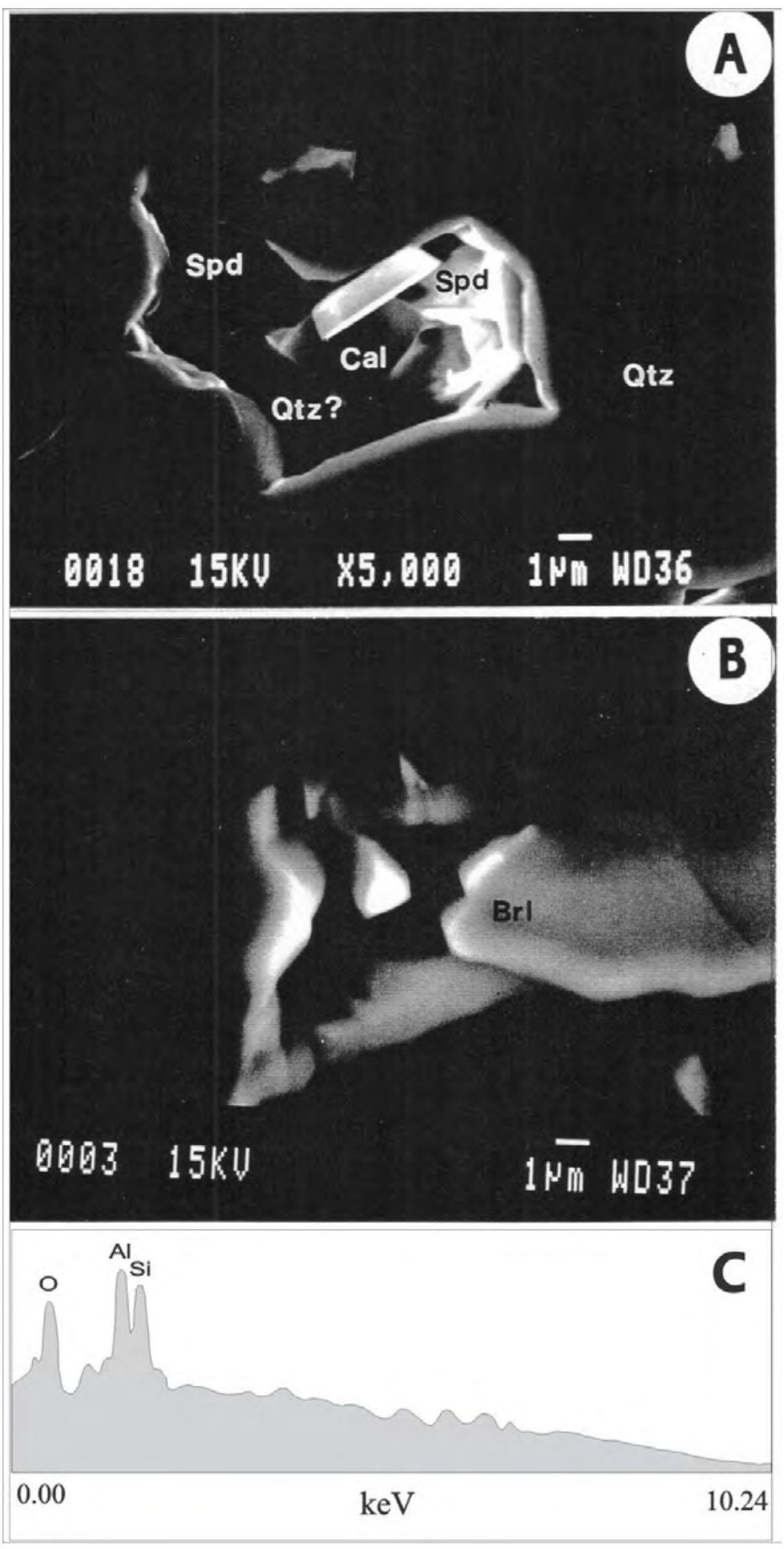

Fig. 11. A) A back-scattered SEM image of an unidentified prismatic crystal in a multi-solid-bearing fluid inclusion hosted by quartz; B). The same mineral but showing a trigonal cross-section in a beryl-hosted fluid inclusion. C). An EDS spectrum of the trigonal solid. 


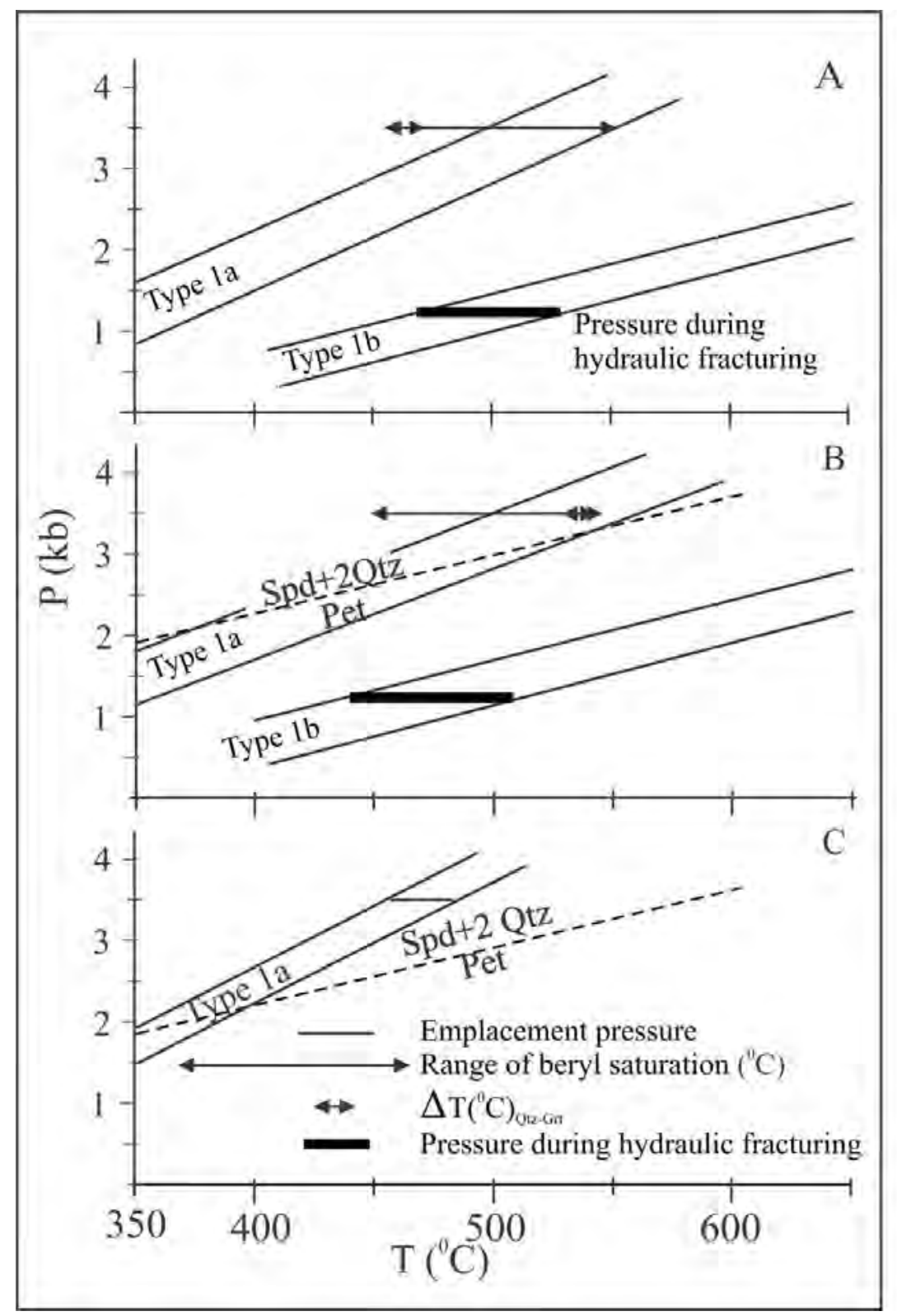

Fig. 12. P-T conditions of formation of beryl pegmatite (A), beryl + spodumene pegmatite (B), and spodumene pegmatite $(\mathrm{C})$ as deduced from limiting isochores representing one standard deviation above and below the mean isochores of type 1a and $1 \mathrm{~b}$ inclusions in beryl, type 1 inclusions in spodumene, and mean isochores of type 1 fluid incluions in quartz. Superimposed are the quartz-garnet oxygen isotope geothermometer (this study), the beryl saturation temperature range (after Evensen et al. 1999) and the stability fields of petalite, spodumene plus quartz (London, 1984). The pressure of $3.5 \mathrm{~Kb}$ is that estimated for emplacement of the pegmatites (Powell 1994), and of $1.7 \mathrm{~Kb}$ is that inferred for hydraulic fracturing of the pegmatites by using the pressure gradients of Sibson (1994). 


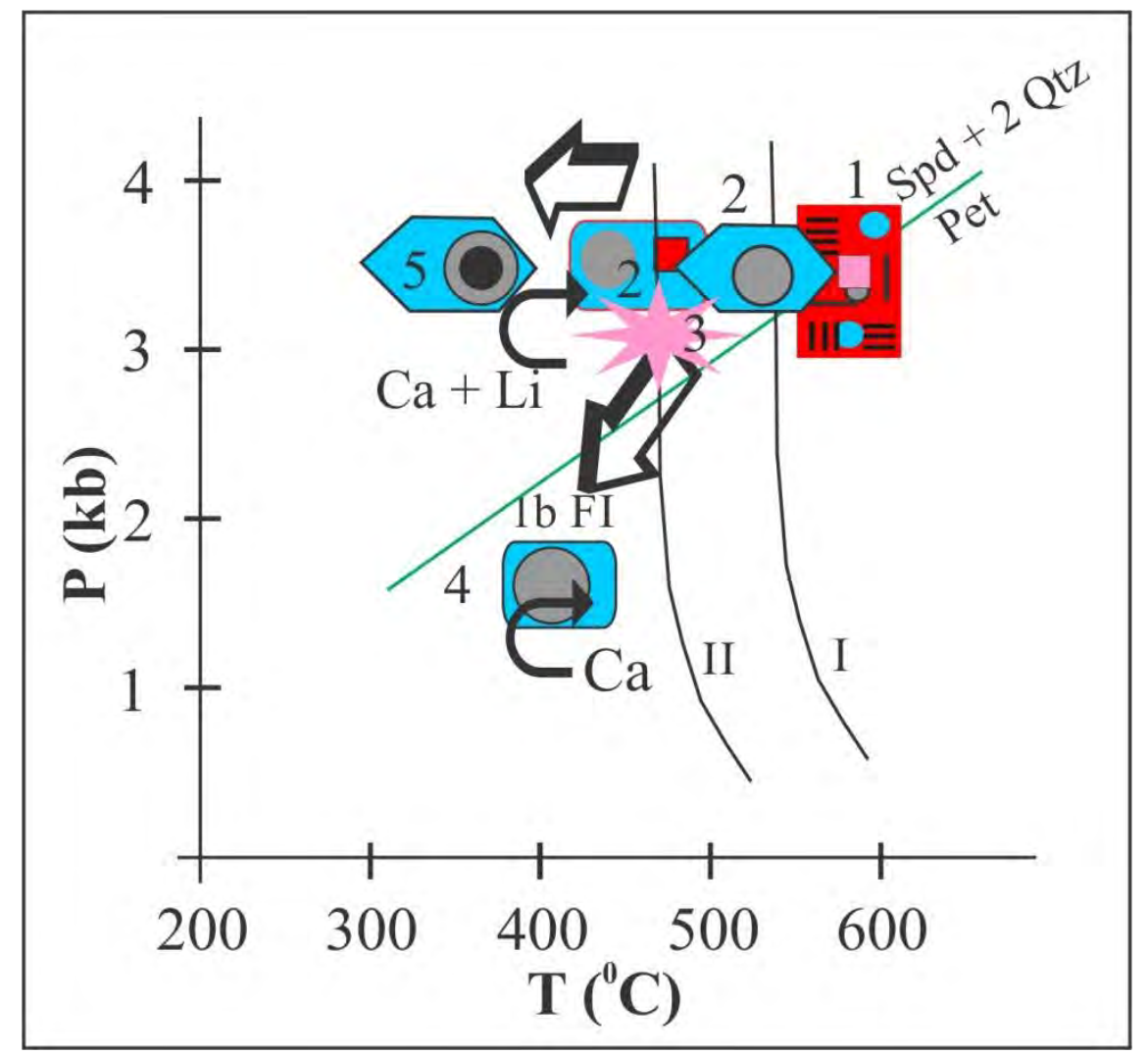

Fig. 13. The interpreted P-T path of fluid evolution in the Lacorne rare-element pegmatite system. 1) emplacement of the hydrous pegmatite-forming liquid at approximately $550-640{ }^{\circ} \mathrm{C}$ within the petalite field, 2) crystallization of beryl and spodumene, and entrapment of type 1a and 2 fluid inclusions; and expulsion of exsolved fluids from spodumene-forming melts upon emplacement, inducing brecciation and $\mathrm{Li}$ exometasomatism in the country rocks and $\mathrm{Ca}$ addition to the pegmatite, 3) local hydrofracturing leading to a temporary drop in fluid pressure in beryl-bearing pegmatites, 4) entrapment of high salinity fluid inclusions and incursion of Ca-bearing brines, 5) unmixing of the orthomagmatic fluid into aqueous and $\mathrm{CO}_{2}$ phases. I. Water-saturated granite solidus (Johannes and Holtz, 1991). II. Lithium-bearing granite solidus with 1 wt.\% $\mathrm{Li}_{2} \mathrm{O}$ (Wyllie and Tuttle, 1964). The solidus for the Lacorne pegmatite-forming magma was likely to be around $350{ }^{\circ} \mathrm{C}$ (see text). 